\title{
Role of FoxO transcription factors in aging and age-related metabolic and neurodegenerative diseases
}

\author{
Shuqi Du and Hui Zheng ${ }^{*}$ (i)
}

\begin{abstract}
Aging happens to all of us as we live. Thanks to the improved living standard and discovery of life-saving medicines, our life expectancy has increased substantially across the world in the past century. However, the rise in lifespan leads to unprecedented increases in both the number and the percentage of individuals 65 years and older, accompanied by the increased incidences of age-related diseases such as type 2 diabetes mellitus and Alzheimer's disease. FoxO transcription factors are evolutionarily conserved molecules that play critical roles in diverse biological processes, in particular aging and metabolism. Their dysfunction is often found in the pathogenesis of many age-related diseases. Here, we summarize the signaling pathways and cellular functions of FoxO proteins. We also review the complex role of FoxO in aging and age-related diseases, with focus on type 2 diabetes and Alzheimer's disease and discuss the possibility of FoxO as a molecular link between aging and disease risks.
\end{abstract}

Keywords: Aging, FoxO, Age-related disease, Type 2 diabetes mellitus, Alzheimer's disease

\section{Introduction}

The FoxO transcription factor family belongs to the Forkhead box transcription factors consisting of DAF16 in Caenorhabditis elegans, dFOXO in Drosophila Melanogaster, and four members in mammals: FoxO1, FoxO3, FoxO4 and FoxO6. FoxO proteins receive and integrate various upstream signals and, through posttranslational modifications and cytoplasmic-to-nucleus trafficking, transcriptionally control a wide range of downstream targets in both peripheral tissues and the central nervous system (CNS). Of particular significance, FoxO is an integral component of the insulin and insulin-like growth factor signaling pathway that plays essential and evolutionarily conserved functions in cellular metabolism, aging and longevity. Dysfunction of this pathway is a major cause of type 2 diabetes mellitus

*Correspondence: huiz@bcm.edu

Huffington Center on Aging, Baylor College of Medicine, Houston, TX, USA
(T2DM), a metabolic disorder influenced by age. Interestingly, accumulating evidence indicates that T2DM is associated with an increased risk of developing Alzheimer's disease (AD), which is the most common cause of dementia in the elderly. Recognized as a neurodegenerative disorder, $\mathrm{AD}$ is also accompanied by significant metabolic disturbances in the brain. Given its prominent role in metabolic homeostasis and organismal longevity, misregulation of the FoxO signaling pathway may underlie both age-associated functional decline and age-related diseases. This review highlights the diverse functions of FoxO in physiology, aging and disease. We will start by describing the molecular characteristics of the FoxO proteins, followed by their cellular signaling pathways and associated activities. Next we will review their physiological functions, with particular emphasis on aging and lifespan regulation across species and CNS function in the mammalian system. Lastly we will summarize the published literature highlighting a critical role of FoxO in age-associated original author(s) and the source, provide a link to the Creative Commons licence, and indicate if changes were made. The images or other third party material in this article are included in the article's Creative Commons licence, unless indicated otherwise in a credit line to the material. If material is not included in the article's Creative Commons licence and your intended use is not permitted by statutory regulation or exceeds the permitted use, you will need to obtain permission directly from the copyright holder. To view a copy of this licence, visit http://creativecommons.org/licenses/by/4.0/. The Creative Commons Public Domain Dedication waiver (http://creativeco mmons.org/publicdomain/zero/1.0/) applies to the data made available in this article, unless otherwise stated in a credit line to the data. 
metabolic and neurodegenerative diseases, in particular $\mathrm{T} 2 \mathrm{DM}$ and $\mathrm{AD}$, and provide our perspective on how these two diseases with distinct clinical presentations may be connected through FoxO signaling and regulation.

\section{FoxO transcription factors}

\section{FoxO proteins and functional domains}

The FoxO proteins have a conserved winged-helix DNA-binding domain (DBD) known as the Forkhead domain. They bind to DNA duplexes as monomers and recognize two consensus sequences, the DAF-16 family member-binding element (DBE) $5^{\prime}$-GTAAA(T/C)AA- $3^{\prime}$ and the insulin responsive element (IRE) $5^{\prime}-(\mathrm{C} / \mathrm{A})(\mathrm{A} / \mathrm{C})$ $\operatorname{AAA}(\mathrm{C} / \mathrm{T}) \mathrm{AA}-3^{\prime}$ [1]. In addition to the DBD, FoxO proteins also carry a nuclear localization signal, a nuclear export signal, and a C-terminal transactivation domain (Fig. 1). These functional structures together with numerous post-translational modifications (PTMs) tightly control FoxO's subcellular localization and transcription activity and afford its sophisticated regulation of various biological processes.

\section{FoxO signaling pathways}

FoxO activity is mainly regulated by its PTMs and subsequent subcellular translocation between the cytosol and the nucleus, where it transcriptionally controls a wide range of downstream targets. In addition, FoxO PTMs also influence its binding affinity with its cofactors, resulting in distinct transcription profiles [9]. Two evolutionarily conserved pathways exist to regulate FoxO activities in cells (Fig. 2). The canonical insulin and growth factor signaling initiates when secreted insulin or insulin-like growth factors (IGFs) bind to their cell surface receptors. Dimerized receptors trigger a series of autophosphorylation and recruit insulin receptor substrate 1-4 (IRS14) and phosphatidylinositol 3-kinase (PI3K), the latter increases the local concentrations of phosphatidylinositol (3,4,5)-trisphosphate (PIP3). PIP3 acts as a second messenger to activate phosphoinositide-dependent kinase 1 (PDK1) and protein kinase B (AKT or PKB). Active AKT translocates to the nucleus and phosphorylates FoxO at three conserved residues, enhancing the binding of FoxO proteins to 14-3-3 and leading to their cytoplasmic localization. Inactivation of FoxO favors cellular growth under normal conditions. The other pathway involves FoxO's

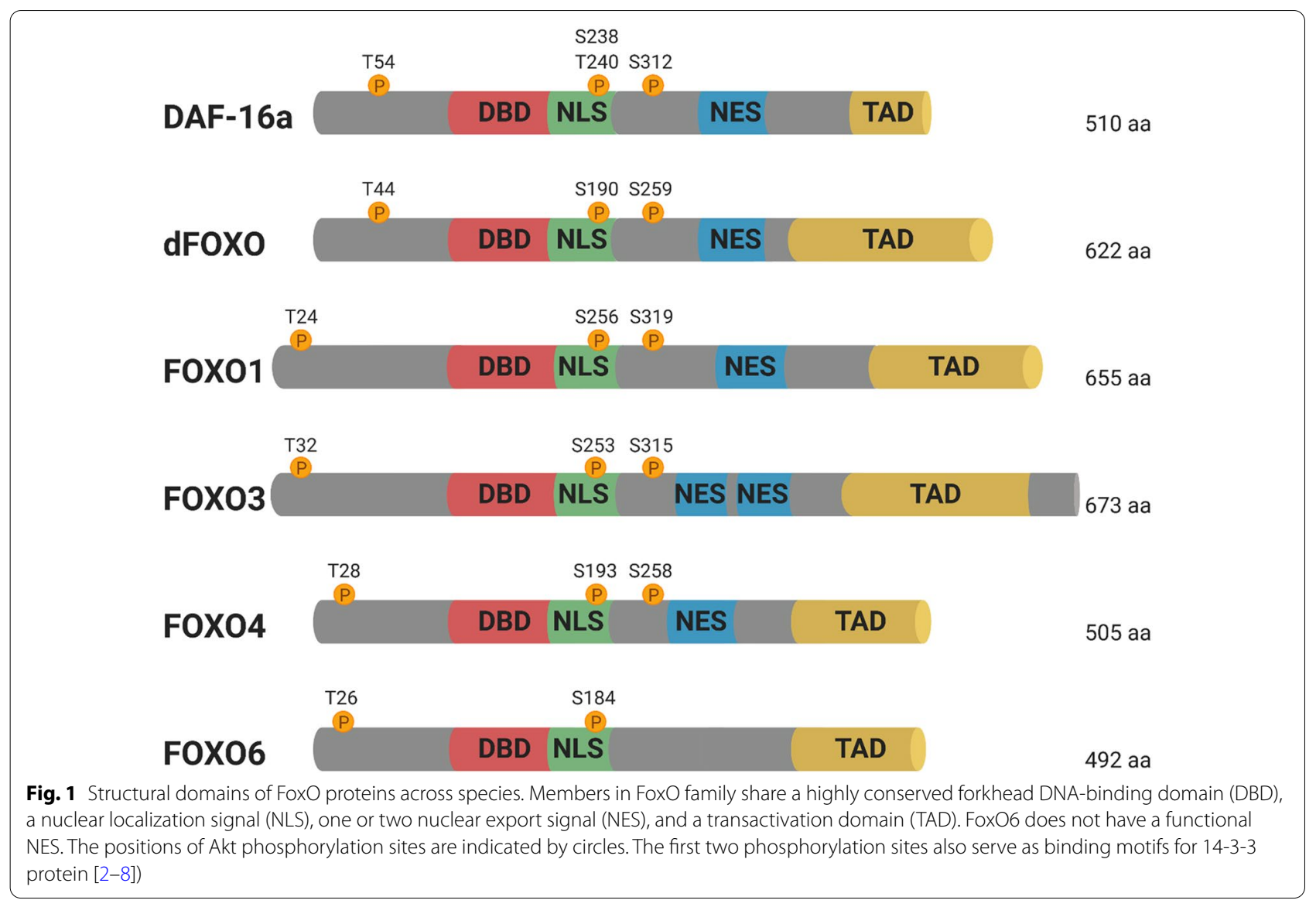




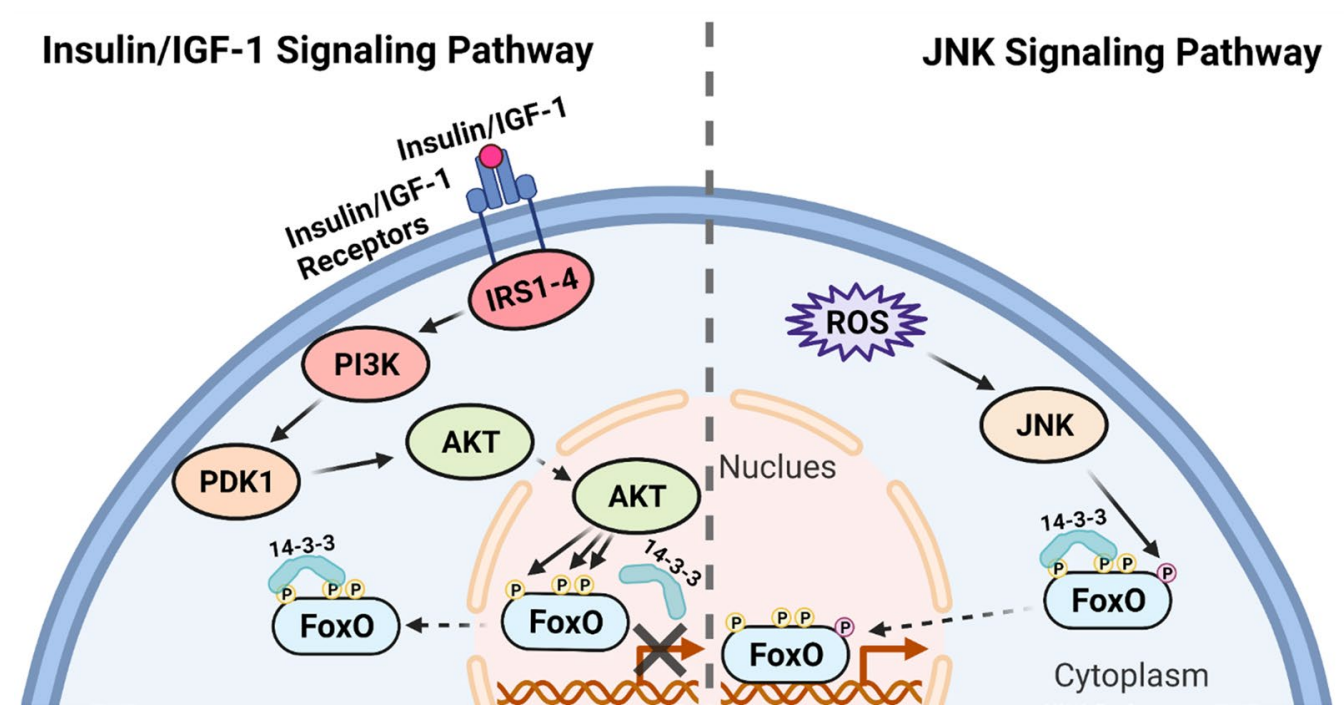

Fig. 2 Evolutionarily conserved Insulin/IGF-1 signaling pathway and JNK signaling pathway for FoxO regulation. The binding of Insulin or IGF-1 to the receptors trigger a kinase cascade, which results in FoxO phosphorylation, 14-3-3 binding and nuclear export (left). Cellular ROS stimulates JNK, which phosphorylates and activates FoxO, leading to its nuclear transport (right) [24]

role in stress response. When cells are in a stressed condition, such as increasing levels of reactive oxygen species (ROS), c-Jun N-terminal kinase (JNK) is activated and phosphorylates cytoplasmic FoxO. This stimulatory phosphorylation induces the release of FoxO from 14-3-3 and upregulates its transcriptional activity. Importantly, the opposing regulation of FoxO activity by insulin/IGF pathway and JNK pathway is evolutionarily conserved in C. elegans, Drosophila and vertebrates $[10,11]$.

In addition to the two well-established mechanisms described above, numerous other signaling events affect FoxO activity. For example, AMP-activated protein kinase (AMPK), an enzyme stimulated by a high AMP to ATP ratio, phosphorylates and activates FoxO for stress resistance [12]. Surprisingly, this phosphorylation event of FoxO does not alter their subcellular localization. Meanwhile, cyclin-dependent kinases (CDKs) activates FoxO to control the expression of many essential cell cycle components during proliferation [13, 14]. Furthermore, regulation of FoxO activities by ataxia telangiectasia mutated (ATM) and ATM Rad3-related (ATR) proteins have been reported in response to DNA damage [15]. However, the regulation of FoxO goes beyond phosphorylation. In fact, other PTMs are also involved to modulate FoxO functions. The effect of acetylation on FoxO proteins is controlled by the histone acetyltransferases and histone deacetylases (HDACs). Studies have shown that HDAC-mediated deacetylation of FoxO leads to its nuclear translocation and transcriptional activation under nutrient deprivation [16]. On the other hand, the degradation of cytoplasmic FoxO proteins rely on the ubiquitin-proteasome pathway. E3 ubiquitin ligase S-phase kinase associated protein 2 (SKP2) and mouse double minute 2 homolog (MDM2) recognizes FoxO with certain inhibitory phosphorylation or acetylation signals and induces their polyubiquitination for degradation $[17,18]$. Under stress conditions like accumulative ROS in cells, MDM2 promotes FoxO mono-ubiquitination as well [19]. Instead of promoting degradation, this modification has a stimulatory effect on FoxO. Lastly, methylation by protein arginine methyltransferase $1 / 6$ (PRMT1/6) and O-GlcNacylation by O-GlcNAc transferase (OGT) have been characterized to impact FoxO activity by blocking the addition of other functional PTMs, adding another layer of complexity to FoxO regulation [20-23].

\section{Cellular functions of FoxO}

Since their first identification as chromosomal translocation partners in acute myeloid leukemia and alveolar rhabdomyosarcomas, FoxO functions have been extensively studied in cell culture systems $[25,26]$. These efforts revealed FoxO as versatile regulators of many essential cellular processes including metabolism, autophagy, cell cycle arrest, DNA damage repair, apoptosis as well as oxidative stress resistance (Fig. 3). Importantly, although FoxO proteins share highly conserved consensus binding sequences, they not only exhibit distinct regulatory features, but also show high cell-type specificity. As most other transcription factors, the binding of FoxO to coactivators or corepressors and the binding of these complexes to other gene regulators ultimately determine the 


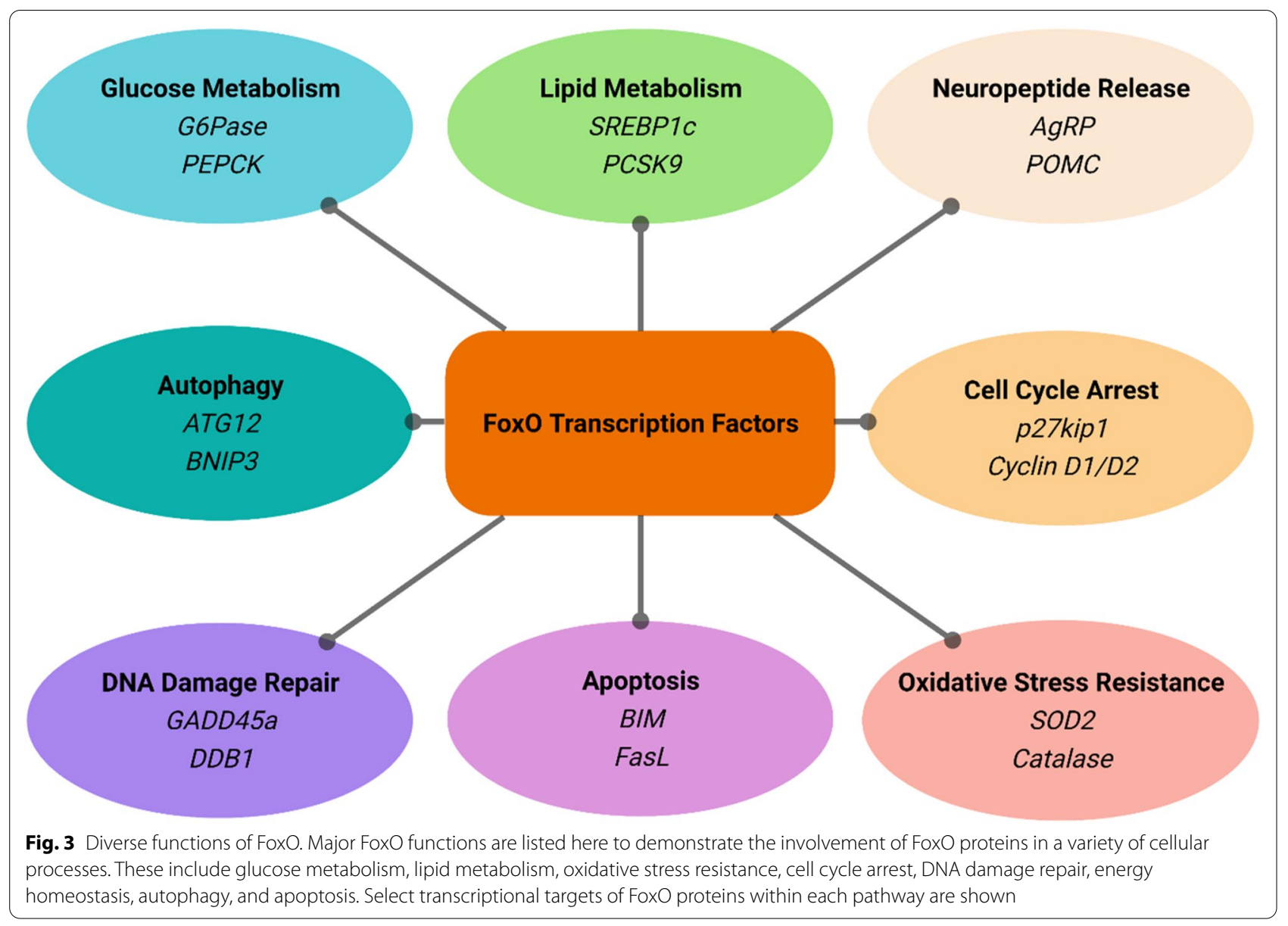

outcome of the gene regulation. In consistency, knockout studies of FoxO members revealed distinct phenotypes. Deletion of Foxo1 leads to embryonic lethality due to defects in angiogenesis during early development. Foxo3 knockout mice are viable, but females become infertile after 15 weeks because of the premature primordial follicle activation and subsequent depletion. Foxo6 deficiency attenuates hepatic gluconeogenesis and impairs memory consolidation. Loss of Foxo4, however, does not result in overt anomalies in mice [27, 28]. Therefore, it is crucial to delineate individual FoxO functions in a context-dependent manner [29].

\section{FoxO regulation of metabolism}

Insulin is a peptide hormone secreted by beta cells in the pancreatic islets under high blood glucose conditions. It has a potent effect on promoting the cellular uptake and utilization of glucose and stimulating anabolic pathways like glycogenesis, lipogenesis, and protein synthesis. As a critical downstream effector of the insulin signaling pathway, FoxO proteins respond to the changing nutrients and regulate the metabolic homeostasis in various tissues and organs. Liver is highly sensitive to insulin and its proper physiological function depends on FoxO's regulation. In hepatocytes, active FoxO1, FoxO3 and FoxO6 induce the expression of two key enzymes in gluconeogenesis, glucose-6-phosphatase (G6Pase) and phosphoenolpyruvates carboxykinase (PEPCK) [30-34]. Consistently, knockout of either Foxo1 alone or Foxo1/3/4 altogether specifically in mouse liver leads to lower blood glucose levels under both fasting and non-fasting conditions [35, 36]. Foxo6 germline knockout mice also exhibit reduced levels of fasting and non-fasting blood glucose [28]. Additionally, FoxO proteins inhibit glycolysis through suppression of glucokinase and pyruvate kinase gene expression [37, 38]. Taken together, liver FoxO contributes to the maintenance of normal blood glucose. Furthermore, FoxO1 is activated in skeletal muscle following strong stress conditions such as starvation, streptozotocin-induced diabetes, or exercise, where it induces the expression of pyruvate dehydrogenase kinase 4 (PDK4) to conserve glucose and gluconeogenesis substrate and decrease the glycolytic flux during energy deprivation [39-41]. 
Besides glucose metabolism, FoxO also plays an important role in lipid homeostasis by regulating lipogenesis, fatty acid oxidation, lipid transport and cholesterol metabolism. FoxO1 transcriptionally suppresses the lipogenic master regulator sterol regulatory element binding protein 1c (SREBP1c) in the liver and regulates the expression of several genes in fatty acid biosynthesis pathway such as fatty acid synthase, acetyl-CoA carboxylase alpha and stearoyl-CoA desaturase I ( $S c d 1)$ [42-44]. As well, FoxO activates the expression of lipolysis and fatty acid oxidation genes including lipoprotein lipase (LPL) and carnitine palmitoyltransferase-1 (CPT1) [40, 44]. Interestingly, FoxO can also promote breakdown of lipid droplets through lipophagy, an autophagy subtype that selectively targets lipid contents, by inducing the transcription of autophagy-related genes like ATG5, ATG12, ATG14 and BECN1 [45, 46]. In addition, FoxO1 drives the secretion of liver triglycerides into plasma. It is achieved by direct promoter binding and transcriptionally elevating the expression of apolipoprotein ApoC-III $[47,48]$. On the other hand, fatty acid uptake and subsequent oxidation are under the control of FoxO1 in muscle cells, where its expression alters the subcellular distribution of fatty acid translocase (FAT/CD36) [49]. In line with the regulation of the fatty acid pathway, FoxO3 suppresses the expression of SREBP-2, the master regulator of cholesterol biosynthesis [50]. It can also promote the low-density lipoprotein (LDL)-cholesterol breakdown by downregulating the level of proprotein convertase subtilisin/kexin type 9 (PCSK9) to preserve the LDL receptor (LDLR)-mediated clearance activity [51]. Meanwhile, FoxO1 regulates cholesterol conversion to bile acids by modulating bile acid biosynthetic genes like CYP7A1 and CYP8B1 [52, 53].

The impact of FoxO on metabolic regulation goes beyond peripheral organs. Researchers have observed FoxO1 expression in hypothalamus, the food intake control center in the brain, where it regulates the expression of neuropeptides and affects appetite. It receives and integrates signals of nutritional status and responds by the release of neuropeptides, such as proopiomelanocortin (POMC) and agouti-related peptides (AgRP) [54]. Within the hypothalamus, the arcuate nucleus (ARC) is the "first-order center" for food intake regulation. It contains two groups of neurons, anorexigenic POMC neurons and orexigenic AgRP neurons [55]. FoxO1 is expressed in both types of neurons, and it is located in the nucleus during starvation but translocated to the cytoplasm after feeding [56]. FoxO1 stimulates appetite by direct promoter binding to Agrp and Pomc genes, with an activation effect on AgRP but inhibiting POMC expression $[57,58]$. Consistent with this finding, mice with a hypothalamic-specific knock-in allele overexpressing Foxo1 showed increased food intake and decreased energy expenditure [59].

\section{FoxO regulation of autophagy}

Autophagy is an evolutionarily conserved self-degradative process through which damaged organelles or macromolecules are broken down and recycled within the cell. Autophagy provides cells with alternative energy sources at critical times during development or under nutrient stress, maintains cellular proteostasis, and eliminates invading pathogens. Three forms of autophagy have been identified based on the way cellular components are sequestered and degraded. Microautophagy is characterized by direct lysosomal engulfment of cytoplasmic molecules. Chaperon-mediated autophagy is a selective degradation pathway which involves HSC70-dependent chaperone recognition of specific cargo proteins and subsequent delivery to the lysosome compartment. Macroautophagy (herein referred to as autophagy) is the most well-studied form and it encapsulates cytoplasmic materials with a special structure called autophagosome that fuses with lysosome for cargo degradation. The autophagy process is divided into different stages based on the presence of some featured structures. Upon activation, autophagy is initiated with the formation of a crescent-shaped double-membrane structure called phagophore. Phagophore grows around and sequesters target components and becomes an autophagosome. The autophagosome then fuses with a lysosome and turns into an autolysosome, where sequestered contents are degraded. The successful completion of these sequential steps involves a number of conserved autophagy-related (ATG) proteins and other autophagy regulators [60].

The autophagy regulatory role of the FoxO family was first described in studies of muscle atrophy in murine models, in which FoxO1 and FoxO3 were found to elevate the autophagic flux by increasing the expression of autophagy genes such as Ulk2, Becn1, Lc3b, Atg12, GabarapL1 and Bnip3 $[61,62]$. Besides its transcriptional activity, Zhao and colleagues demonstrated that cytosolic FoxO1 was responsible for the autophagy induction in human cancer cell lines under oxidative stress or serum starvation. Specifically, SIRT2 acetylates FoxO1 upon stress and the acetylated FoxO1 binds to ATG7 to trigger the autophagy machinery [63]. This discovery was unexpected, as under environmental conditions that favor autophagy induction, FoxO proteins are more likely present in the nucleus. In a follow-up study, they also found that FoxO3 could induce autophagy under the same settings but in a FoxO1-dependent way. It transcriptionally activates the expression of upstream regulator PIK3CA, which then results in FoxO1 phosphorylation and nuclear export [64]. In addition to general autophagy, FoxO3 is 
involved in the regulation of mitophagy, an autophagy subtype that selectively targets mitochondria. This pathway is mediated by PINK1, a central mitophagy regulator and contributes to the redox homeostasis in the cells [65-67].

\section{FoxO regulation of other cellular pathways}

Other than autophagy and metabolism, FoxO transcription factors are also well known for their regulation in processes like cell cycle arrest, DNA damage repair, apoptosis and oxidative stress resistance. The activation of FoxO, either by transcriptional overexpression or pharmacologically targeting upstream regulators, resulted in a robust cell cycle arrest in cancer cell lines of colon carcinoma, glioblastoma, osteosarcoma, and acute $\mathrm{T}$ cell leukemia [68-70]. This FoxO-dependent proliferation regulation is mediated through transcription of multiple cell cycle kinase inhibitors like p2 $7^{\mathrm{kip} 1}$ and downregulation of the expression of cyclin D1 and D2 [71-73]. In addition, FoxO3 can stimulate the expression of GADD45a or DDB1 for DNA damage repair during paused division $[74,75]$. Besides cell cycle control, FoxO proteins are well-described inducers of apoptosis in different cell types. They can drive the expression of many pro-apoptotic genes including FASL, TRAIL, TNFR, BIM and $B M F$, leading to programmed cell death in both normal and cancer cells [76]. The importance of this function is implicated in the fact that a variety of cancers inactivate FoxO to promote their survival. In addition, FoxO proteins have also been intensively studied in their role of oxidative stress response. They act to enhance cellular detoxification via the induction of superoxide dismutase 2 (SOD2) and catalase expression. By protecting cells from ROS accumulation, FoxO reduces the risk of cancer development [77]. Other examples of FoxO functions include the negative regulation of RUNX2 by FoxO1 and FoxO4, which mitigated the migration and invasion of prostate cancer $[78,79]$. Studies have also found that FoxO3 deficiency led to the activation of inflammatory $\mathrm{NF} \kappa \mathrm{B}$ pathway and increased tumor burden in mouse colon [80, 81].

\section{Physiological functions of FoxO FoxO in aging and longevity \\ C. elegans}

In 1990s, longevity studies in C. elegans led to the identification of the insulin/insulin-like growth factor-1 signaling (IIS) pathway as the first established lifespanregulating signaling pathway in animals [82]. To be specific, genetic mutations that nullify the activity of DAF-2, the invertebrate insulin/insulin-like growth factor-1 receptor, more than double the lifespan of the worms [83]. Mutants with reduced activity of the IIS signaling component AGE-1, the C. elegans homolog of mammalian PI3K, also exhibit extended longevity [84, 85]. Remarkably, the longevity phenotype associated with IIS reduction is completely dependent on DAF-16, the FoxO homolog in C. elegans. Over the past 20 years, other longevity-regulating factors have been reported and for many of them, their functions on aging require direct or indirect involvement of DAF-16 activity. Overexpression of JNK-1 or CST-1 promotes lifespan extension by phosphorylating and activating DAF-16 [86, 87]. The loss of RLE-1, an E3 ubiquitin ligase that catalyzes DAF16 polyubiquitination, extends lifespan [88]. In contrast, the deubiquitylase MATH-33 stabilizes DAF-16 and its loss of function inhibits the longevity phenotype of daf2 mutants [89]. In addition, transcription factors like HSF-1, SKN-1 and PQM-1 can function as cofactors for DAF-16 to synergistically mediate the extended lifespan induced by IIS inhibition [90-92]. Germline removal by laser microsurgery or genetic mutation of $g l p-1$ increases lifespan independent of IIS pathway but this benefit also relies on DAF-16 activity [93-96]. Although DAF-16 is not required for the lifespan extension effect of chronic calorie restriction in eat-2 mutant [97], it is indispensable in longevity induced by calorie restriction in middleaged worms or by intermittent fasting [98, 99]. At the molecular level, activation of DAF-16 by upstream signaling pathways leads to its translocation to the nucleus, where it binds to the chromosome and either activates or represses downstream genes in metabolism, autophagy, and stress response [100-102]. It is believed that the combined effects of DAF-16-mediated transcriptional changes leads to the lifespan extension in C. elegans [103].

\section{Drosophila}

Similar to worms, reduced IIS also promotes longevity in Drosophila and the extension of lifespan is dependent on the downstream transcription factor dFOXO, the fly homolog of FoxO and DAF-16 [104, 105]. However, unlike DAF-16, direct manipulation of dFOXO expression in certain tissues is sufficient to extend lifespan in Drosophila. Overexpression of dFOXO in adult Drosophila pericerebral fat body led to reduced neuronal expression of insulin-like peptides, as well as increased lifespan and fecundity $[106,107]$. More recently, reduced IIS specifically in an astrocyte-like glia subtype was found to delay development and extend healthy lifespan in Drosophila in a dFOXO-dependent manner [108]. Although $\mathrm{dFOXO}$ is not required for the lifespan extension by dietary restriction [109], it mediates the negative effect of sugar-rich diet on longevity [110]. Mechanistically, studies have shown that increased fat storage and oxidative 
stress resistance are implicated in $\mathrm{dFOXO}$-mediated lifespan extension $[104,106]$.

\begin{abstract}
Mammals
Multiple long-lived mouse models have been created by genetic manipulations targeting growth hormone, IGF1, IGF-1 receptor, insulin receptor, and insulin receptor substrate [111-116]. However, some of the modifications also lead to negative changes like growth defects and insulin resistance $[112,116]$. FoxO3 was reported to be required for lifespan extension under dietary restriction condition [117], but its implication in IIS inhibitioninduced longevity or the overexpression phenotype have yet to be elucidated.
\end{abstract}

Several genetic variations within $\mathrm{FOXO} 3$ have been reported to be associated with human longevity in a number of geographical and ethnic groups [118-123]. These FOXO3 single nucleotide polymorphisms (SNPs) in long-lived men and women were associated with lower prevalence of cancer and cardiovascular diseases along with higher insulin sensitivity $[118,124]$. A study on two intronic FOXO3 SNPs, rs12206094-T and rs4946935A, revealed that both longevity-linked minor alleles are associated with enhanced promoter activity in cell-based assays and higher FOXO3 mRNA expression in many human tissues [125]. Another intronic FOXO3 SNP rs2802292 G-allele was also found to be associated with increased FOXO3 basal expression in population [126, 127]. It is proposed that these SNP-associated introns have a regulatory role on FOXO3 expression [128]. More work is needed before a causal relationship between FOXO3 and human longevity can be established.

\section{FoxO in brain development and CNS function}

The mammalian brain is made up of two basic types of cells: neurons and glia. Glia can be further categorized into more specific types based on their morphology and functions, such as astrocytes, microglia, and oligodendrocytes. Neurons are the key players in the brain that serve as information processors and messengers while the star-shaped astrocytes support neuronal functions through facilitating synaptic signaling, supplying energy and nutrition as well as stress resolution. Microglia are the immune cells in the brain. They patrol the brain and respond to inflammatory stimuli. Oligodendrocytes, on the other hand, wrap around neuronal axons to form myelin sheaths, speeding up the transmission of electrical impulses along the exons.

FoxOs, as versatile transcription factors mediating various cellular processes, play important roles in the brain both during development and in adult. FoxO proteins show differential expression patterns in adult mouse brains. FoxO1 is strongly expressed in dentate gyrus and the ventral CA regions of the hippocampus as well as in striatum, whereas FoxO3 is more diffusely expressed throughout the brain including all hippocampal areas, cortex and cerebellum. FoxO6 shows significant expression across hippocampus, the amygdalohippocampal area and the shell of the nucleus accumbens. The expression of FoxO4, however, is very limited in the brain [129-131]. Genetic deletion of Foxo genes in the mouse brain results in varied phenotypes. Germline Foxo3 null mice develop adult-onset auditory neuropathy making them partially deaf due to incorrectly positioned synapses within the cochlea [132]. Foxo6 knockout mice are capable of learning but have a reduced ability to form long-term contextual and object recognition memories, probably due to lower dendritic spine density in hippocampal neurons [133]. Brain-specific deletion of Foxo1 driven by the Nestin promoter results in increased anxiety in a forced swim test, contrary to the reduced anxiety in Foxo3-deficient mice [134]. Besides the neuronal phenotypes, ablation of Foxo1 using the Synapsin 1 promoter driven Cre in mice leads to a blunted refeeding response, increased sensitivity to leptin and amino acid signaling, and increased locomotor activity [135]. Its deletion in sympathetic nervous system results in reduced catecholamine biosynthesis, lower energy expenditure, improved glucose clearance and increased bone mass [136].

FoxO proteins are well recognized for their ability to integrate upstream stress signals to initiate fate-determination programs such as survival or apoptosis, and this is also applicable to neurons. It was shown that in $\mathrm{PC} 12$ cells or primary cultured neurons, FoxO3 regulates apoptosis upon nerve growth factor (NGF) deprivation [137]. Further studies suggested that this response is downstream of FasL and JNK signaling pathways [138]. FoxO1 is also involved in neuronal apoptosis downstream of NMDA receptor signaling by controlling the expression of TXNIP [139]. Moreover, MST1 can phosphorylate both FoxO1 and FoxO3 in cerebellar granule neurons under ROS or NGF withdraw to stimulate their transcriptional activity leading to cell death [87, 140]. In contrast, methylation of FoxO3 by methyltransferase SET9 impairs its activity and contributes to granule cell survival [141]. In addition, FoxO3 was found to mediate neuronal autophagy, the suppression of which via either genetic knockdown or expression of an upstream microRNA displayed neuroprotective effects upon traumatic brain injury (TBI) [142, 143]. Interestingly, mitochondrial FoxO3 was also detected in hippocampal neurons where it was proposed to confer protection against glutamate toxicity during epilepsy [144].

Neural stem cells (NSCs) in the brain are capable of self-renewal or giving rise to new neurons and certain types of glial cells. Adult NSCs are mostly localized to 
the subventricular zone (SVZ) and subgranular zone (SGZ) where they are under tight control of proliferation and differentiation throughout life [145]. Knockout of Foxo1/3/4 or Foxo3 alone is sufficient to reduce the quiescence of NSCs, causing them to hyper-proliferate and, as a consequence, results in the depletion of the stem cell pool early in life. These FoxO-deficient NSCs also exhibit other phenotypes like decreased self-renewal and increased apoptosis and high ROS levels [146-148]. In addition, new-born neurons lacking FoxO exhibits altered dendritic morphology, increased spine density and aberrant spine positioning [149]. Mechanistically, Schäffner and colleagues found that proper NSC differentiation requires the involvement of autophagy machinery and this process is FoxO dependent [149].

FoxO's function in the brain is not limited to neurons. FoxO3 was found to upregulate aquaporin 4 (AQP4), a water channel specifically expressed in astrocytes, to induce cerebral edema following TBI [150]. FoxO3 also keeps the astrocytes cell cycle in check and its expression significantly inhibits proinflammatory cytokine-induced astrocytes proliferation by activating cell cycle regulatory genes like $\mathrm{p} 27^{\mathrm{kip} 1}$. Consistent with this observation, Foxo3-null mice exhibits severe astrogliosis [151]. In microglia, FoxO3 was shown to mitigate ROS by transactivating antioxidant genes such as Sod2 and Cat, and this process is under the regulation of deacetylase sirtuin-3 (SIRT3) [152]. Moreover, it has been reported that FoxO1-mediated p2 $7^{\text {kip1 }}$ expression is indispensable for oligodendrocyte regeneration after neonatal hypoxia [153], while it is also responsible for nitric oxide-induced apoptosis in the oligodendroglial culture [154].

Recent work in our lab further delineated the cell-type specific role of FoxO3 in the brain [155]. We showed that in primary cultures, the subcellular localization of FoxO3 in astrocytes is highly sensitive to the changes of upstream insulin signaling but the same treatments triggered no response of FoxO3 translocation in neurons. Using conditional knockout and AAV-mediated rescue of FoxO3 expression in mice, we confirmed the cortical astrogliosis phenotype reported in Foxo3-null mice [151] and demonstrated that the phenotype can be attributed to the cell-autonomous function of FoxO3 in astrocytes. Additionally, FoxO3 deficiency altered the expression of a subset of lipid-regulatory genes and the overall lipid profile in the cortex. Using primary astrocyte cultures, we found that Foxo3 deletion not only impeded cellular ability to consume excess fatty acids, but also impaired mitochondrial function and blunted the capacity to uptake extracellular $A \beta$. All these dysfunctions could be rescued by astroglial AAV-FoxO3 overexpression. Given the critical role of astrocytes in maintaining brain homeostasis, loss of astrocytic FoxO3 may exacerbate neuronal vulnerability, particularly under pathological conditions such AD.

\section{Role of FoxO in age-associated diseases Type 2 diabetes mellitus}

T2DM is a chronic metabolic disease that is most prevalent in older adults. In the past 20 years, the number of adults diagnosed with T2DM has more than doubled and it is currently the seventh leading cause of death in the United States. T2DM features hyperglycemia, insulin resistance and relative impairment in insulin secretion. The disease has both local and systematic manifestations and its pathophysiology closely involves FoxO. For example, the level and the subcellular localization of FoxO differ in pancreatic $\beta$ cells at different stages of T2DM. Researchers observed predominantly inactive cytoplasmic FoxO1 in healthy $\beta$ cells, but it is translocated to the nucleus in response to hyperglycemia. In advanced diabetes, FoxO1 disappears from $\beta$ cells, accompanied with the loss of insulin signaling. It was proposed that FoxO1 preserves the balance of mitochondrial function by promoting the utilization of glucose over lipids. The dynamic behavior of FoxO1 reflects its role in mitigating $\beta$ cell stress at an early stage but becomes exhausted when the disease proceeds [156-158]. Furthermore, FoxO is overactivated in many other organs including liver and skeletal muscles under insulin resistance conditions where it partakes clinical symptoms. Hepatic FoxO drives hyperglycemia by inducing the expression of G6Pase [159]. It can also promote hyperlipidemia by pushing the production and release of very low-density lipoprotein (VLDL)triacylglycerol [34]. Moreover, FoxO's regulation on bile acids through CYP8B1 is disrupted, resulting in more $12 \alpha$-hydroxylated bile acids secretion. $12 \alpha$-hydroxylated bile acids are less potent than non-12 $\alpha$-hydroxylated bile acids at inhibiting triacylglycerol and cholesterol synthesis, which contributes to the atherogenic lipid profile in T2DM [53]. Studies have shown that induction of diabetes in mice causes muscle atrophy due to upregulated ubiquitin-proteasome and autophagy clearance. However, triple knockout of Foxo1/3/4 prevents the activation of protein degradation pathways and rescued the muscle loss [160].

\section{Alzheimer's disease}

$\mathrm{AD}$ is the most common form of dementia in the elderly population. Patients experience progressive loss of memory and other cognitive abilities, which isolates them from family and society and eventually leading to death. $\mathrm{AD}$ is ranked as the sixth leading cause of death in the United States and costs 18.6 billion hours of care from unpaid caregivers in 2019, a contribution valued at nearly 244 billion dollars [161]. 
$\mathrm{AD}$ is pathologically characterized by the accumulation of extracellular senile plaques and intraneuronal neurofibrillary tangles (NFTs) in the brain. Senile plaques are aggregates of amyloid beta (A $\beta)$ peptides while NFTs are mainly phosphorylated tau inclusions [162, 163]. Accordingly two major hypotheses have emerged based on the pathologic hallmarks $[164,165]$. $A \beta$ is derived from amyloid precursor protein (APP) through sequential cleavage. APP processing through the amyloidogenic pathway requires two enzymes, $\beta$-secretase and $\gamma$-secretase, which subsequently cleave APP leading to the release of $\mathrm{A} \beta$ peptides (Fig. 4). $\mathrm{A} \beta$ is rapidly degraded under normal conditions, however, in aged individuals or under pathological conditions, the clearance capacity is impaired, resulting in $A \beta$ accumulation and aggregation. $A \beta_{40}$ and $A \beta_{42}$ are two common species of $A \beta$ peptides, with $A \beta_{42}$ being more prone to aggregation. Increased production of $A \beta_{42}$ or a rise in ratio of $A \beta_{42} / A \beta_{40}$ from dysregulated cleavage often precede the formation of amyloid plaque. The amyloid hypothesis of $\mathrm{AD}$ pathogenesis proposed that the accumulated $A \beta$ amyloid will develop into senile plaques, causing neurotoxicity and induction of tau pathology, eventually leading to neuronal cell death and neurodegeneration [166]. Alternatively, the tau hypothesis posits that the principal causative substance of $\mathrm{AD}$ is tau, a microtubule-associated protein that regulate the stability of tubulin assemblies. Hyperphosphorylated tau proteins under pathological conditions aggregate inside of neurons, disrupting the cellular homeostasis and causing neurodegeneration (Fig. 5). The amyloid hypothesis is strongly supported by the facts that amyloid deposits are a unique feature of $\mathrm{AD}$ and all identified genetic mutations in early-onset familial AD can be mapped to APP or presenilin $1 / 2$, components of $\gamma$-secretase, and impact $A \beta$ production. Nonetheless, the tau hypothesis agrees better with pathological staging of the disease and correlates with cognitive decline $[166,167]$. The $A \beta$ and tau pathologies trigger other neuropathological features that likely modulate disease progression. In particular, synapse dysfunction and loss show the strongest correlation with

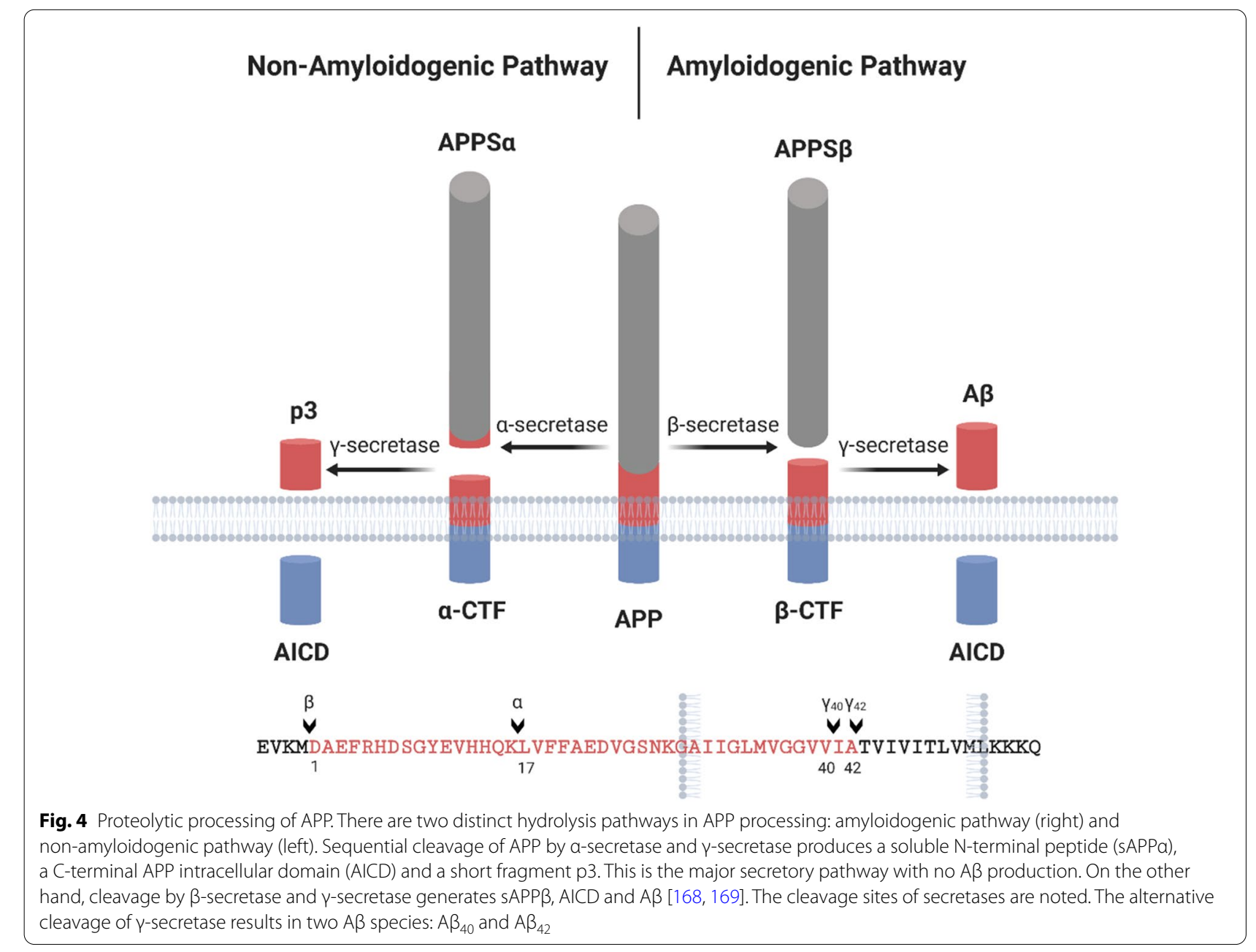



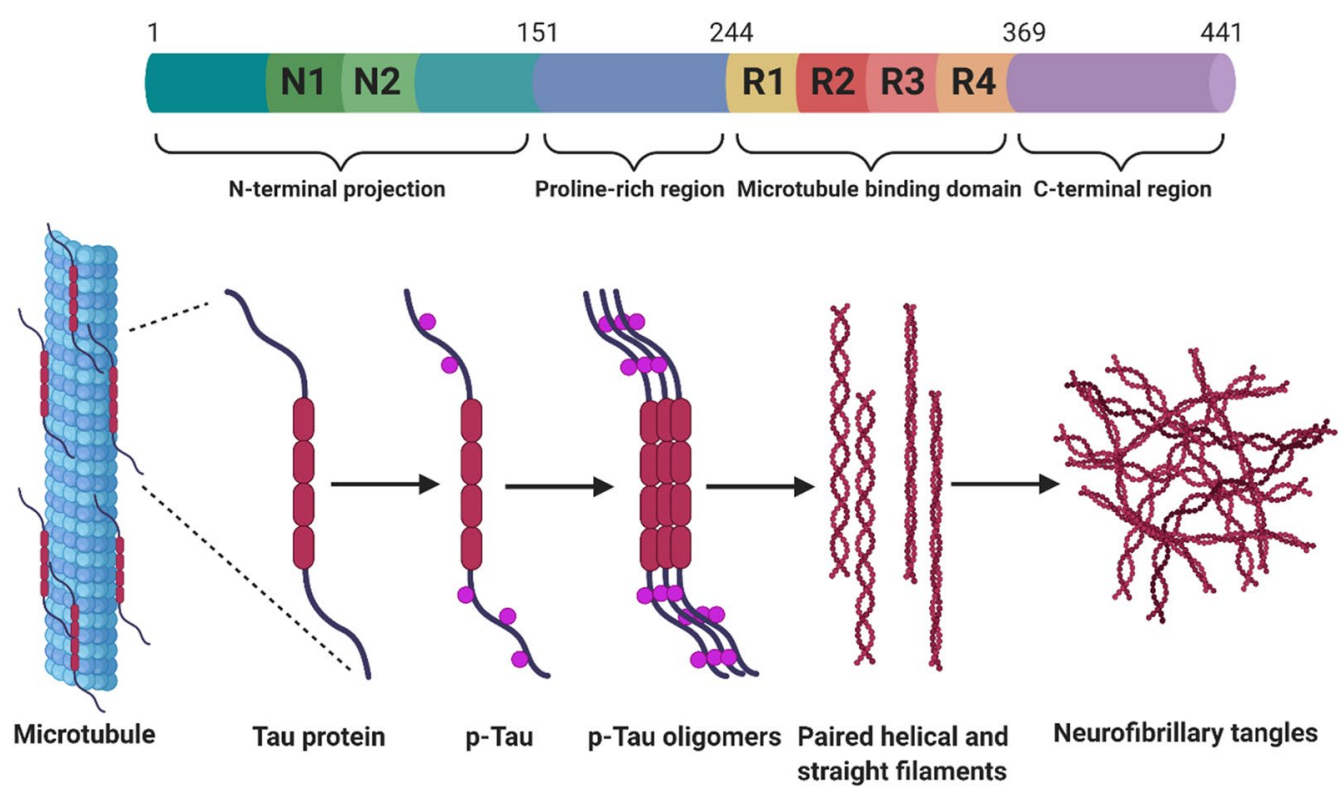

Fig. 5 The functional domains of tau and its aggregation process. The alternative splicing of human MAPT gene generates six isoforms of tau proteins. They differ from each other by the presence or absence of one or two N-terminal inserts (N1, N2) and by bearing either three (R1, R3, R4) or four (R1, R2, R3 and R4) repeat domains. The structure of the longest isoform is shown here. The repeat domains are important for microtubule binding as well as aggregation under pathological conditions. It is believed that tau stabilizes microtubules in neurons and this process is regulated by kinases and phosphatases. Abnormally hyperphosphorylated tau ( $p$-tau) dissociates from microtubules and form oligomers. The aggregation continues and leads to the assembly of paired helical filaments or straight filaments, and eventually forming neurofibrillary tangles $[170,171]$

cognitive decline in $\mathrm{AD}$ patients. Neuroinflammation due to glial cell hyper-activation can impinge neuronal survival and function through secretion of toxic molecules and/or loss of trophic support.

Multiple studies implicate FoxO in AD pathophysiology although its exact role remains controversial. Several papers showed that FoxO proteins, especially FoxO3, mediate $A \beta$ or AICD-induced apoptosis in primary cell cultures and in Drosophila, which leads to the loss of neurons or astrocytes [172-178]. FoxO3 has also been shown to be involved in $\mathrm{A} \beta$-induced mitochondrial dysfunction in cultured neurons [179]. Qin and colleagues reported attenuation of amyloid pathology in a caloric restricted AD mouse model (Tg2576), and this is associated with activation of the insulin signaling pathway and downregulation of FoxO3 [180]. However, other reports demonstrated a protective role of FoxO in the brain. FoxO has been shown to protect neurons against $A \beta$-induced toxicity by upregulating stress resistance genes [181, 182]. Moreover, Drosophila FoxO (dFOXO) is essential for the maintenance of autophagy in the fly brain, and its reduction during aging promotes $A \beta$-induced neuronal dysfunction [183]. Interestingly, in mouse and monkey models of T2DM, researchers observed that reduced FoxO activities correlated with elevated $\mathrm{A} \beta$ and phosphorylated tau level, implicating a connection of T2DM and
AD through FoxO [184]. Shi and colleagues proposed a two-sided role of FoxO3, with it being neuroprotective in the beginning but neurotoxic at later stages in $\mathrm{AD}$ [185]. They found that FoxO3, as a direct target of CDK5, promoted survival in HT22 cells under glutamate treatment by upregulating the oxidative stress resistant gene $\operatorname{Sod} 2$ while it switched to a proapoptotic pathway after prolonged exposure in a BIM- and FASL-dependent manner. FoxO3 also mediated the glutamate induced $\mathrm{A} \beta$ production and consistently, the authors found activation and upregulation of FoxO3 in hippocampal neurons precede neurodegeneration and plaque formation in p25 transgenic mice [185].

Our study of FoxO3 in the 5xFAD mouse model supports a beneficial role of astrocytic FoxO3 against the amyloid pathology [155]. We found that Nestin-Cre mediated conditional knockout of Foxo3 in 5xFAD mice significantly aggravated the plaque burden in the cortex compared to the littermate $5 \mathrm{xFAD}$ control. Increased plaque pathology was accompanied by enhanced synaptic loss and reduced recruitment of reactive astrocytes to the plaque location. Surprisingly, we also observed a blunted response of reactive microglia in the proximity of plaques. In contrast, AAV-mediated astrocyte-specific expression of FoxO3 in 5xFAD mice ameliorated the cortical plaque load, enhanced synapse number and also 
promoted the recruitment of both astrocytes and microglia to the plaques. Taken together, these results suggest that astrocytic FoxO3 modulates amyloid pathology through both a cell-autonomous effect and by influencing the recruitment of plaque-associated microglia.

\section{Other neurodegenerative diseases}

In addition to $\mathrm{AD}$, FoxO has been implicated in other neurodegenerative diseases like Parkinson's disease (PD) and Huntington's disease (HD). PD affects predominately dopaminergic neurons in the substantia nigra, and its symptoms include tremor, bradykinesia, limb rigidity and balance problems. During the course of PD, $\alpha$-synuclein aggregates and accumulates in affected neurons to form Lewy bodies and ultimately causes neuronal death. Researchers have shown opposing roles of FoxO3 in dopaminergic neurons expressing $\alpha$-synuclein. On the one hand, expression of a constitutively active form of FoxO3 induced degradation of $\alpha$-synuclein and clearance of defective mitochondria. On the other hand, dominant negative forms of FoxO3 protected against death of dopaminergic neurons [186, 187]. Thus, while FoxO3 can protect cells from $\alpha$-synuclein toxicity, it may also be responsible for neuronal death. In a rat model of $\mathrm{PD}$, FoxO3 was found to inhibit the apoptosis in nigral dopaminergic neurons in a CDKN2D-dependent manner [188]. Likewise, the dFOXO function varies in different PD models in Drosophila. It ameliorates the mitochondrial defects and neuronal degeneration in PINK1 null mutants while contributes to dopaminergic neurodegeneration in LRRK2-linked PD $[189,190]$.

$\mathrm{HD}$ is an autosomal dominant disease caused by an expanding poly-Q tract in the huntingtin (HTT) protein. It features abnormal involuntary movements, cognitive decline, and psychiatric disorders. Similar to the AD and PD studies, there are contrasting reports on FoxO's role in HD. FoxO3 has been show in some studies to stimulate HD progression [191-193], whereas in other studies HD development was alleviated by FoxO [194, 195]. It is possible that the influence of FoxO3 activity differs with different stages of the disease. Interestingly, Vidal and colleagues unveiled a new mechanism of FoxO function in HD, where the loss of the unfolded protein response (UPR) transcription factor XBP1 leads to augmented expression of FoxO1, thus promoting autophagy and mutant HTT clearance [196].

Altogether, the published literature support a prominent role of FoxO in $\mathrm{AD}$ and other neurodegenerative diseases. However, its effect is likely dynamic and cell type-, context- and disease stage-dependent, which may explain the distinct and opposite results observed. Additional studies are needed to elucidate the underlying mechanisms and functional outcomes of FoxO in these diseases.

\section{Summary and perspectives}

Aging is a complex process, and so are age-related diseases. FoxO transcription factors play a crucial role in both aging and age-related diseases, and thus could potentially serve as an underlying molecular link. Intriguingly, certain features of FoxO we learned from aging studies are consistent with those observed in disease context. For example, in C. elegans and Drosophila, the lifespan extension exerted by FoxO is likely the result of a combined autocrine and paracrine effects. DAF-2 is believed to primarily function in the nervous system. Mosaic worms with daf-2 deficiency in a neuronal lineage and epidermis showed significantly increased lifespan [197]. In addition, expression of $d a f-2$ using neural promoters normalized the lifespan of daf-2 mutants to control levels [198]. However, expression of daf-16 in neurons only achieved $5-20 \%$ of lifespan extension in daf-16; daf-2 animals. In contrast, restoration of DAF-16 activity in intestine, which is also the worm's adipose tissue, is sufficient to extend their lifespan by $50-60 \%$ and it can also completely rescue the longevity defect of daf-16 germline mutants [199]. Similarly, in Drosophila, limited activation of $\mathrm{dFOXO}$ in pericerebral fat body reduced the insulin-like peptide synthesis in neurons, and thus increases the lifespan of the animal [106]. It is possible that FoxO activity modulates lipid metabolism in these lipid storing cells, which in turn influence neuronal endocrine processes and lifespan in a non-cell autonomous manner. Strikingly, in mouse CNS, we found FoxO3 deficiency disrupts lipid metabolism in astrocytes, the glial cells which store and catabolize most lipids in the brain. In an amyloid mouse model, we showed that astrocytic FoxO3 not only function cell-autonomously, but also recruit microglia to engage amyloid plaques [155]. Although how FoxO3's function in astrocytes affects cell-cell communication awaits further investigation, this interaction resembles what is observed in aging studies. Besides astrocyte-microglia interaction, it would also be interesting to understand whether astrocytic FoxO3 communicate with neurons and how these intercellular crosstalk modulate neuronal function and amyloid and tau/NFT pathology.

Accumulating evidence supports the existence of a shared risk for AD and T2DM [200]. The pathogenesis of $\mathrm{AD}$ is accompanied by significant disruption of metabolic pathways in the CNS. For example, AD brains suffer from oxidative stress and impaired glucose metabolism [201], and they take on features of insulin resistance [202, 203]. In addition, $A D$ patients were found to carry more extensive islet amyloid, a pathogenic feature of T2DM, 
than non-AD controls [204]. Further, multiple reports implicate T2DM as a risk factor for AD development. Research in rodents demonstrated AD-like neuropathology in T2DM models and accelerated pathology development in AD models with T2DM-like metabolic changes induced by high-fat diet [205-209]. However, how peripheral insulin resistance modulates the central insulin signaling remains controversial. Studies in murine and primate models of T2DM showed an upregulated insulin signaling in affected brain, implying decreased FoxO activity under this condition [184]. We have shown that CNS FoxO3 deficiency leads to aggravated cortical amyloid pathology [155]. It has also been reported that FoxO mitigates $\beta$ cell stress in early T2DM but such an effect is blunted when the disease proceeds [156, 157]. Age-associated decline of FoxO expression correlates with higher incidence of age-related diseases in the elderly population $[155,210]$. Thus, proper levels of FoxO activity may be important not only for lifespan regulation but also confer protection against age-related diseases. Upregulation of FoxO activity thus holds therapeutic promise in the prevention or treatment of these age-related diseases. The fact that FoxO can be modulated by phosphorylation and other PTMs makes it an attractive target druggable by small chemicals. However, due to the complexity of the FoxO regulation and function, the level, site and duration of FoxO need to be tightly controlled. Therefore, in-depth understanding of each FoxO protein under different physiological and pathological conditions at molecular, cellular, and functional levels are needed to decipher their role in aging and disease to inform the development of future therapeutics.

\footnotetext{
Abbreviations

T2DM: Type 2 diabetes mellitus; AD: Alzheimer's disease; C. elegans: Caenorhabditis elegans; DBD: DNA-binding domain; DBE: DAF-16 family memberbinding element; IRE: Insulin responsive element; PTMs: Post-translational modifications; NLS: Nuclear localization signal; NES: Nuclear export signal; TAD: Transactivation domain; IGFs: Insulin-like growth factors; IRS: Insulin receptor substrate; PI3K: Phosphatidylinositol 3-kinase; PIP3: Phosphatidylinositol $(3,4,5)$-trisphosphate; PDK1: Phosphoinositide-dependent kinase 1; PKB: Protein kinase B; ROS: Reactive oxygen species; JNK: C-Jun N-terminal kinase; AMPK: AMP-activated protein kinase; CDKs: Cyclin-dependent kinases; ATM: Ataxia telangiectasia mutated; ATR: ATM Rad3-related; HDACs: Histone deacetylases; SKP2: S-phase kinase associated protein 2; MDM2: Mouse double minute 2 homolog; PRMT1/6: Protein arginine methyltransferase 1/6; OGT: O-GIcNAc transferase; G6Pase: Glucose-6-phosphatase; PEPCK: Phosphoenolpyruvates carboxykinase; PDK4: Pyruvate dehydrogenase kinase 4; SREBP1c: Sterol regulatory element binding protein 1c; Scd1: Stearoyl-CoA desaturase I; LPL: Lipoprotein lipase; CPT1: Carnitine palmitoyltransferase-1; FAT: Fatty acid translocase; LDL: Low-density lipoprotein; PCSK9: Proprotein convertase subtilisin/kexin type 9; LDLR: LDL receptor; POMC: Proopiomelanocortin; AgRP: Agouti-related peptides; ARC: Arcuate nucleus; ATG: Autophagyrelated; SOD2: Superoxide dismutase 2; IIS: Insulin/insulin-like growth factor-1 signaling; DBH: Dopamine- $\beta$-hydroxylase; NGF: Nerve growth factor; CGNs: Cerebellar granular neurons; TBI: Traumatic brain injury; NSCs: Neural stem cells; SVZ: Subventricular zone; SGZ: Subgranular zone; AQP4: Aquaporin 4; SIRT3: Deacetylase sirtuin-3; VLDL: Very low density lipoprotein; NFTs: Neurofibrillary tangles; AB: Amyloid beta; APP: Amyloid precursor protein; AICD: APP
}

intracellular domain; PD: Parkinson's disease; HD: Huntington's disease; HTT: Huntingtin; UPR: Unfolded protein response.

\section{Acknowledgements}

We thank members of the Zheng laboratory for suggestions and edits.

\section{Authors' contributions}

SD and $\mathrm{HZ}$ discussed and approved the overall structure of the review. SD wrote the first draft and prepared the figures. Additional drafts were written by $\mathrm{SD}$ and $\mathrm{HZ}$. Both authors read and approved the final manuscript.

\section{Funding}

This work was supported by grants from the NIH (RF1 NS093652, R01

AG057509, R01 AG020670, RF1 AG062257 and P01 AG066606 to HZ).

Availability of data and materials

Not applicable.

\section{Declarations}

Ethics approval and consent to participate

Not applicable.

Consent for publication

Not applicable.

\section{Competing Interests}

The authors declare that they have no competing interests.

Received: 16 October 2021 Accepted: 20 October 2021

Published online: 02 November 2021

\section{References}

1. Obsil T, Obsilova V. Structural basis for DNA recognition by FOXO proteins. Biochim Biophys Acta. 2011;1813(11):1946-53.

2. Ma J, Matkar S, He X, Hua X. FOXO family in regulating cancer and metabolism. Semin Cancer Biol. 2018;50:32-41.

3. Psenakova K, Kohoutova K, Obsilova V, Ausserlechner MJ, Veverka V, Obsil T. Forkhead domains of FOXO transcription factors differ in both overall conformation and dynamics. Cells. 2019. https://doi.org/10. 3390/cells8090966.

4. Paradis S, Ruvkun G. Caenorhabditis elegans Akt/PKB transduces insulin receptor-like signals from AGE-1 PI3 kinase to the DAF-16 transcription factor. Genes Dev. 1998;12(16):2488-98.

5. Lin K, Hsin H, Libina N, Kenyon C. Regulation of the Caenorhabditis elegans longevity protein DAF-16 by insulin/IGF-1 and germline signaling. Nat Genet. 2001;28(2):139-45.

6. Kramer JM, Davidge JT, Lockyer JM, Staveley BE. Expression of Drosophila FOXO regulates growth and can phenocopy starvation. BMC Dev Biol. 2003;3:5.

7. Junger MA, Rintelen F, Stocker H, Wasserman JD, Vegh M, Radimerski T, Greenberg ME, Hafen E. The Drosophila forkhead transcription factor FOXO mediates the reduction in cell number associated with reduced insulin signaling. J Biol. 2003;2(3):20.

8. Kang P, Chang K, Liu Y, Bouska M, Birnbaum A, Karashchuk G, Thakore R, Zheng W, Post S, Brent CS, et al. Drosophila Kruppel homolog 1 represses lipolysis through interaction with dFOXO. Sci Rep. 2017;7(1):16369.

9. Oellerich MF, Potente M. FOXOs and sirtuins in vascular growth, maintenance, and aging. Circ Res. 2012;110(9):1238-51.

10. van der Horst A, Burgering BM. Stressing the role of FoxO proteins in lifespan and disease. Nat Rev Mol Cell Biol. 2007;8(6):440-50.

11. Bridge D, Theofiles AG, Holler RL, Marcinkevicius E, Steele RE, Martinez DE. FoxO and stress responses in the cnidarian Hydra vulgaris. PLoS ONE. 2010;5(7): e11686.

12. Greer EL, Oskoui PR, Banko MR, Maniar JM, Gygi MP, Gygi SP, Brunet $A$. The energy sensor AMP-activated protein kinase directly 
regulates the mammalian FOXO3 transcription factor. J Biol Chem. 2007;282(41):30107-19.

13. Yuan Z, Becker EB, Merlo P, Yamada T, DiBacco S, Konishi Y, Schaefer EM, Bonni A. Activation of FOXO1 by Cdk1 in cycling cells and postmitotic neurons. Science. 2008;319(5870):1665-8.

14. Huang H, Regan KM, Lou Z, Chen J, Tindall DJ. CDK2-dependent phosphorylation of FOXO1 as an apoptotic response to DNA damage. Science. 2006;314(5797):294-7.

15. Matsuoka S, Ballif BA, Smogorzewska A, McDonald ER 3rd, Hurov KE, Luo J, Bakalarski CE, Zhao Z, Solimini N, Lerenthal Y, et al. ATM and ATR substrate analysis reveals extensive protein networks responsive to DNA damage. Science. 2007;316(5828):1160-6.

16. Beharry AW, Sandesara PB, Roberts BM, Ferreira LF, Senf SM, Judge AR. HDAC1 activates FoxO and is both sufficient and required for skeletal muscle atrophy. J Cell Sci. 2014;127(Pt 7):1441-53.

17. Huang H, Regan KM, Wang F, Wang D, Smith DI, van Deursen JM, Tindal DJ. Skp2 inhibits FOXO1 in tumor suppression through ubiquitin-mediated degradation. Proc Natl Acad Sci USA. 2005;102(5):1649-54.

18. Yang JY, Zong CS, Xia W, Yamaguchi H, Ding Q, Xie X, Lang JY, Lai CC, Chang CJ, Huang WC, et al. ERK promotes tumorigenesis by inhibiting FOXO3a via MDM2-mediated degradation. Nat Cell Biol. 2008;10(2):138-48.

19. Brenkman AB, de Keizer PL, van den Broek NJ, Jochemsen AG, Burgering BM. Mdm2 induces mono-ubiquitination of FOXO4. PLOS ONE. 2008;3(7): e2819.

20. Yamagata K, Daitoku H, Takahashi Y, Namiki K, Hisatake K, Kako K, Mukai H, Kasuya Y, Fukamizu A. Arginine methylation of FOXO transcription factors inhibits their phosphorylation by Akt. Mol Cell. 2008;32(2):221-31.

21. Kuo M, Zilberfarb V, Gangneux N, Christeff N, Issad T. O-GIcNAC modification of $\mathrm{FoxO} 1$ increases its transcriptional activity: a role in the glucotoxicity phenomenon? Biochimie. 2008;90(5):679-85.

22. Eijkelenboom A, Burgering BM. FOXOs: signalling integrators for homeostasis maintenance. Nat Rev Mol Cell Biol. 2013;14(2):83-97.

23. Wang Z, Yu T, Huang P. Post-translational modifications of FOXO family proteins (review). Mol Med Rep. 2016;14(6):4931-41.

24. Hay N. Interplay between FOXO, TOR, and Akt. Biochim Biophys Acta. 2011;1813(11):1965-70.

25. Galili N, Davis RJ, Fredericks WJ, Mukhopadhyay S, Rauscher FJ 3rd, Emanuel BS, Rovera G, Barr FG. Fusion of a fork head domain gene to PAX3 in the solid tumour alveolar rhabdomyosarcoma. Nat Genet. 1993;5(3):230-5.

26. Hillion J, Le Coniat M, Jonveaux P, Berger R, Bernard OA. AF6q21, a novel partner of the $M L L$ gene in $t(6 ; 11)(q 21 ; q 23)$, defines a forkhead transcriptional factor subfamily. Blood. 1997;90(9):3714-9.

27. Hosaka T, Biggs WH 3rd, Tieu D, Boyer AD, Varki NM, Cavenee WK, Arden KC. Disruption of forkhead transcription factor (FOXO) family members in mice reveals their functional diversification. Proc Natl Acad Sci USA. 2004;101(9):2975-80.

28. Calabuig-Navarro V, Yamauchi J, Lee S, Zhang T, Liu YZ, Sadlek K, Coudriet GM, Piganelli JD, Jiang CL, Miller R, et al. Forkhead Box O6 (FoxO6) depletion attenuates hepatic gluconeogenesis and protects against fat-induced glucose disorder in mice. J Biol Chem. 2015;290(25):15581-94.

29. Dansen TB, Burgering BM. Unravelling the tumor-suppressive functions of FOXO proteins. Trends Cell Biol. 2008;18(9):421-9.

30. Ayala JE, Streeper RS, Desgrosellier JS, Durham SK, Suwanichkul A, Svitek CA, Goldman JK, Barr FG, Powell DR, O'Brien RM. Conservation of an insulin response unit between mouse and human glucose-6-phosphatase catalytic subunit gene promoters: transcription factor FKHR binds the insulin response sequence. Diabetes. 1999;48(9):1885-9.

31. Hall RK, Yamasaki T, Kucera T, Waltner-Law M, O'Brien R, Granner DK. Regulation of phosphoenolpyruvate carboxykinase and insulin-like growth factor-binding protein-1 gene expression by insulin. The role of winged helix/forkhead proteins. J Biol Chem. 2000;275(39):30169-75.

32. Schmoll D, Walker KS, Alessi DR, Grempler R, Burchell A, Guo S, Walther R, Unterman TG. Regulation of glucose-6-phosphatase gene expression by protein kinase Balpha and the forkhead transcription factor FKHR. Evidence for insulin response unit-dependent and -independent effects of insulin on promoter activity. J Biol Chem. 2000;275(46):36324-33.
33. Kim DH, Perdomo G, Zhang T, Slusher S, Lee S, Phillips BE, Fan Y, Giannoukakis N, Gramignoli R, Strom S, et al. FoxO6 integrates insulin signaling with gluconeogenesis in the liver. Diabetes. 2011;60(11):2763-74.

34. Lee $\mathrm{S}$, Dong HH. FoxO integration of insulin signaling with glucose and lipid metabolism. J Endocrinol. 2017;233(2):R67-79.

35. Matsumoto M, Pocai A, Rossetti L, Depinho RA, Accili D. Impaired regulation of hepatic glucose production in mice lacking the forkhead transcription factor Foxo1 in liver. Cell Metab. 2007;6(3):208-16.

36. Patel PV, Patel HK, Panchal SS, Mehta TA. Self micro-emulsifying drug delivery system of tacrolimus: formulation, in vitro evaluation and stability studies. Int J Pharm Investig. 2013;3(2):95-104.

37. Xiong $X$, Tao R, DePinho RA, Dong XC. Deletion of hepatic FoxO1/3/4 genes in mice significantly impacts on glucose metabolism through downregulation of gluconeogenesis and upregulation of glycolysis. PLOS ONE. 2013;8(8): e74340.

38. Os I, Zhang W, Wasserman DH, Liew CW, Liu J, Paik J, DePinho RA, Stolz $\mathrm{DB}$, Kahn CR, Schwartz MW, et al. FoxO1 integrates direct and indirect effects of insulin on hepatic glucose production and glucose utilization. Nat Commun. 2015;6:7079.

39. Furuyama T, Kitayama K, Yamashita H, Mori N. Forkhead transcription factor FOXO1 (FKHR)-dependent induction of PDK4 gene expression in skeletal muscle during energy deprivation. Biochem J. 2003;375(Pt 2):365-71.

40. Kamei Y, Mizukami J, Miura S, Suzuki M, Takahashi N, Kawada T, Taniguchi T, Ezaki O. A forkhead transcription factor FKHR upregulates lipoprotein lipase expression in skeletal muscle. FEBS Lett. 2003;536(1-3):232-6.

41. Link W, Fernandez-Marcos PJ. FOXO transcription factors at the interface of metabolism and cancer. Int J Cancer. 2017;141(12):2379-91.

42. Deng X, Zhang W, Os I, Williams JB, Dong Q, Park EA, Raghow R, Unterman TG, Elam MB. FoxO1 inhibits sterol regulatory element-binding protein-1C (SREBP-1C) gene expression via transcription factors Sp1 and SREBP-1C. J Biol Chem. 2012;287(24):20132-43.

43. Haeusler RA, Han S, Accili D. Hepatic FoxO1 ablation exacerbates lipid abnormalities during hyperglycemia. J Biol Chem. 2010;285(35):26861-8.

44. Zhang W, Patil S, Chauhan B, Guo S, Powell DR, Le J, Klotsas A, Matika $R$, Xiao X, Franks $R$, et al. FoxO1 regulates multiple metabolic pathways in the liver: effects on gluconeogenic, glycolytic, and lipogenic gene expression. J Biol Chem. 2006;281(15):10105-17.

45. Xiong $X$, Tao R, DePinho RA, Dong XC. The autophagy-related gene 14 (Atg14) is regulated by forkhead box $\mathrm{O}$ transcription factors and circadian rhythms and plays a critical role in hepatic autophagy and lipid metabolism. J Biol Chem. 2012;287(46):39107-14.

46. Dong XC. FOXO transcription factors in non-alcoholic fatty liver disease. Liver Res. 2017;1(3):168-73.

47. Altomonte J, Cong L, Harbaran S, Richter A, Xu J, Meseck M, Dong HH. Foxo1 mediates insulin action on apoC-III and triglyceride metabolism. J Clin Invest. 2004;114(10):1493-503.

48. Gross DN, van den Heuvel AP, Birnbaum MJ. The role of FoxO in the regulation of metabolism. Oncogene. 2008;27(16):2320-36

49. Bastie CC, Nahle Z, McLoughlin T, Esser K, Zhang W, Unterman T, Abumrad NA. FoxO1 stimulates fatty acid uptake and oxidation in muscle cells through CD36-dependent and -independent mechanisms. J Biol Chem. 2005;280(14):14222-9.

50. Tao R, Xiong X, DePinho RA, Deng CX, Dong XC. Hepatic SREBP-2 and cholesterol biosynthesis are regulated by FoxO3 and Sirt6. J Lipid Res. 2013;54(10):2745-53.

51. Tao R, Xiong X, DePinho RA, Deng CX, Dong XC. FoxO3 transcription factor and Sirt6 deacetylase regulate low density lipoprotein (LDL)-cholesterol homeostasis via control of the proprotein convertase subtilisin/kexin type 9 (Pcsk9) gene expression. J Biol Chem. 2013;288(41):29252-9.

52. LiT, Ma H, Park YJ, Lee YK, Strom S, Moore DD, Chiang JY. Forkhead box transcription factor $\mathrm{O} 1$ inhibits cholesterol 7alpha-hydroxylase in human hepatocytes and in high fat diet-fed mice. Biochim Biophys Acta. 2009;1791(10):991-6.

53. Haeusler RA, Pratt-Hyatt M, Welch CL, Klaassen CD, Accili D. Impaired generation of 12-hydroxylated bile acids links hepatic insulin signaling with dyslipidemia. Cell Metab. 2012;15(1):65-74. 
54. Schwartz MW, Woods SC, Porte D Jr, Seeley RJ, Baskin DG. Central nervous system control of food intake. Nature. 2000;404(6778):661-71.

55. Bagnol D, Lu XY, Kaelin CB, Day HE, Ollmann M, Gantz I, Akil H, Barsh GS, Watson SJ. Anatomy of an endogenous antagonist: relationship between Agouti-related protein and proopiomelanocortin in brain. J Neurosci. 1999;19(18):RC26.

56. Fukuda M, Jones JE, Olson D, Hill J, Lee CE, Gautron L, Choi M, Zigman $J \mathrm{M}$, Lowell BB, Elmquist JK. Monitoring FoxO1 localization in chemically identified neurons. J Neurosci. 2008;28(50):13640-8.

57. Kitamura T, Feng Y, Kitamura YI, Chua SC Jr, Xu AW, Barsh GS, Rossetti L, Accili D. Forkhead protein FoxO1 mediates Agrp-dependent effects of leptin on food intake. Nat Med. 2006;12(5):534-40.

58. Kim MS, Pak YK, Jang PG, Namkoong C, Choi YS, Won JC, Kim KS, Kim SW, Kim HS, Park JY, et al. Role of hypothalamic Foxo1 in the regulation of food intake and energy homeostasis. Nat Neurosci. 2006;9(7):901-6.

59. Sasaki T, Kitamura T. Roles of FoxO1 and Sirt1 in the central regulation of food intake. Endocr J. 2010;57(11):939-46.

60. Parzych KR, Klionsky DJ. An overview of autophagy: morphology, mechanism, and regulation. Antioxid Redox Signal. 2014;20(3):460-73.

61. Mammucari C, Milan G, Romanello V, Masiero E, Rudolf R, Del Piccolo P, Burden SJ, Di Lisi R, Sandri C, Zhao J, et al. FoxO3 controls autophagy in skeletal muscle in vivo. Cell Metab. 2007;6(6):458-71.

62. Milan G, Romanello V, Pescatore F, Armani A, Paik JH, Frasson L, Seydel A, Zhao J, Abraham R, Goldberg AL, et al. Regulation of autophagy and the ubiquitin-proteasome system by the FoxO transcriptional network during muscle atrophy. Nat Commun. 2015;6:6670.

63. Zhao Y, Yang J, Liao W, Liu X, Zhang H, Wang S, Wang D, Feng J, Yu L, Zhu WG. Cytosolic FoxO1 is essential for the induction of autophagy and tumour suppressor activity. Nat Cell Biol. 2010;12(7):665-75.

64. Zhou J, Liao W, Yang J, Ma K, Li X, Wang Y, Wang D, Wang L, Zhang Y, Yin $\mathrm{Y}$, et al. FOXO3 induces FOXO1-dependent autophagy by activating the AKT1 signaling pathway. Autophagy. 2012;8(12):1712-23.

65. Mei Y, Zhang Y, Yamamoto K, Xie W, Mak TW, You H. FOXO3a-dependent regulation of Pink1 (Park6) mediates survival signaling in response to cytokine deprivation. Proc Natl Acad Sci USA. 2009;106(13):5153-8.

66. Song D, Ma J, Chen L, Guo C, Zhang Y, Chen T, Zhang S, Zhu Z, Tian L, Niu P. FOXO3 promoted mitophagy via nuclear retention induced by manganese chloride in SH-SY5Y cells. Metallomics. 2017;9(9):1251-9.

67. Das S, Mitrovsky G, Vasanthi HR, Das DK. Antiaging properties of a grape-derived antioxidant are regulated by mitochondrial balance of fusion and fission leading to mitophagy triggered by a signaling network of Sirt1-Sirt3-Foxo3-PINK1-PARKIN. Oxid Med Cell Longev. 2014;2014: 345105 .

68. Brunet A, Bonni A, Zigmond MJ, Lin MZ, Juo P, Hu LS, Anderson MJ, Arden KC, Blenis J, Greenberg ME. Akt promotes cell survival by phosphorylating and inhibiting a Forkhead transcription factor. Cell. 1999;96(6):857-68.

69. Kops GJ, de Ruiter ND, De Vries-Smits AM, Powell DR, Bos JL, Burgering BM. Direct control of the Forkhead transcription factor AFX by protein kinase B. Nature. 1999;398(6728):630-4.

70. Kops GJ, Medema RH, Glassford J, Essers MA, Dijkers PF, Coffer PJ, Lam EW, Burgering BM. Control of cell cycle exit and entry by protein kinase B-regulated forkhead transcription factors. Mol Cell Biol. 2002;22(7):2025-36

71. Medema RH, Kops GJ, Bos JL, Burgering BM. AFX-like Forkhead transcription factors mediate cell-cycle regulation by Ras and PKB through p27kip1. Nature. 2000;404(6779):782-7.

72. Hornsveld M, Dansen TB, Derksen PW, Burgering BMT. Re-evaluating the role of FOXOs in cancer. Semin Cancer Biol. 2018;50:90-100.

73. Schmidt M, de Fernandez Mattos S, van der Horst A, Klompmaker R, Kops GJ, Lam EW, Burgering BM, Medema RH. Cell cycle inhibition by FoxO forkhead transcription factors involves downregulation of cyclin D. Mol Cell Biol. 2002;22(22):7842-52.

74. Zhang Y, Gan B, Liu D, Paik JH. FoxO family members in cancer. Cancer Biol Ther. 2011;12(4):253-9.

75. Chen YR, Liu MT, Chang YT, Wu CC, Hu CY, Chen JY. Epstein-Barr virus latent membrane protein 1 represses DNA repair through the PI3K/Akt/ FOXO3a pathway in human epithelial cells. JVirol. 2008;82(16):8124-37.

76. Fu Z, Tindall DJ. FOXOs, cancer and regulation of apoptosis. Oncogene. 2008;27(16):2312-9.
77. Coomans de Brachene A, Demoulin JB. FOXO transcription factors in cancer development and therapy. Cell Mol Life Sci. 2016;73(6):1159-72.

78. Zhang H, Pan Y, Zheng L, Choe C, Lindgren B, Jensen ED, Westendorf $\mathrm{J}$, Cheng L, Huang H. FOXO1 inhibits Runx2 transcriptional activity and prostate cancer cell migration and invasion. Cancer Res. 2011;71(9):3257-67.

79. Su B, Gao L, Baranowski C, Gillard B, Wang J, Ransom R, Ko HK, Gelman IH. A genome-wide RNAi screen identifies FOXO4 as a metastasissuppressor through counteracting PI3K/AKT signal pathway in prostate cancer. PLoS ONE. 2014;9(7): e101411.

80. Penrose HM, Cable C, Heller S, Ungerleider N, Nakhoul H, Baddoo M, Hartono AB, Lee SB, Burow ME, Flemington EF, et al. Loss of Forkhead box $\mathrm{O} 3$ facilitates inflammatory colon cancer: transcriptome profiling of the immune landscape and novel targets. Cell Mol Gastroenterol Hepatol. 2019;7(2):391-408.

81. Lin L, Hron JD, Peng SL. Regulation of NF-kappaB, Th activation, and autoinflammation by the forkhead transcription factor Foxo3a. Immunity. 2004;21(2):203-13.

82. Kenyon C. The first long-lived mutants: discovery of the insulin/ IGF-1 pathway for ageing. Philos Trans R Soc Lond B Biol Sci. 2011;366(1561):9-16.

83. Kenyon C, Chang J, Gensch E, Rudner A, Tabtiang R. A C. elegans mutant that lives twice as long as wild type. Nature. 1993;366(6454):461-4.

84. Friedman DB, Johnson TE. A mutation in the age-1 gene in Caenorhabditis elegans lengthens life and reduces hermaphrodite fertility. Genetics. 1988;118(1):75-86.

85. Friedman DB, Johnson TE. Three mutants that extend both mean and maximum life span of the nematode, Caenorhabditis elegans, define the age-1 gene. J Gerontol. 1988;43(4):B102-109.

86. Oh SW, Mukhopadhyay A, Svrzikapa N, Jiang F, Davis RJ, Tissenbaum HA. JNK regulates lifespan in Caenorhabditis elegans by modulating nuclear translocation of forkhead transcription factor/DAF-16. Proc Natl Acad Sci USA. 2005;102(12):4494-9.

87. Lehtinen MK, Yuan Z, Boag PR, Yang Y, Villen J, Becker EB, DiBacco S, de la Iglesia N, Gygi S, Blackwell TK, et al. A conserved MST-FOXO signaling pathway mediates oxidative-stress responses and extends life span. Cell. 2006;125(5):987-1001.

88. Li W, Gao B, Lee SM, Bennett K, Fang D. RLE-1, an E3 ubiquitin ligase, regulates $C$. elegans aging by catalyzing DAF- 16 polyubiquitination. Dev Cell. 2007;12(2):235-46.

89. Heimbucher T, Liu Z, Bossard C, McCloskey R, Carrano AC, Riedel CG, Tanasa B, Klammt C, Fonslow BR, Riera CE, et al. The deubiquitylase MATH-33 controls DAF-16 stability and function in metabolism and longevity. Cell Metab. 2015;22(1):151-63.

90. Hsu AL, Murphy CT, Kenyon C. Regulation of aging and age-related disease by DAF-16 and heat-shock factor. Science. 2003;300(5622):1142-5.

91. Tullet JM, Hertweck M, An JH, Baker J, Hwang JY, Liu S, Oliveira RP, Baumeister R, Blackwell TK. Direct inhibition of the longevitypromoting factor SKN-1 by insulin-like signaling in C. elegans. Cell. 2008;132(6):1025-38.

92. Tepper RG, Ashraf J, Kaletsky R, Kleemann G, Murphy CT, Bussemaker HJ. PQM-1 complements DAF-16 as a key transcriptional regulator of DAF-2-mediated development and longevity. Cell. 2013;154(3):676-90.

93. Hsin $\mathrm{H}$, Kenyon $\mathrm{C}$. Signals from the reproductive system regulate the lifespan of C. elegans. Nature. 1999;399(6734):362-6.

94. Arantes-Oliveira N, Apfeld J, Dillin A, Kenyon C. Regulation of lifespan by germ-line stem cells in Caenorhabditis elegans. Science. 2002;295(5554):502-5.

95. Berman JR, Kenyon C. Germ-cell loss extends C. elegans life span through regulation of DAF-16 by kri-1 and lipophilic-hormone signaling. Cell. 2006;124(5):1055-68.

96. Shen Y, Wollam J, Magner D, Karalay O, Antebi A. A steroid receptormicroRNA switch regulates life span in response to signals from the gonad. Science. 2012;338(6113):1472-6.

97. Apfeld J, O'Connor G, McDonagh T, DiStefano PS, Curtis R. The AMPactivated protein kinase AAK-2 links energy levels and insulin-like signals to lifespan in C. elegans. Genes Dev. 2004;18(24):3004-9.

98. Greer EL, Dowlatshahi D, Banko MR, Villen J, Hoang K, Blanchard D, Gygi SP, Brunet A. An AMPK-FOXO pathway mediates longevity induced by a novel method of dietary restriction in C. elegans. Curr Biol. 2007;17(19):1646-56. 
99. Honjoh S, Yamamoto T, Uno M, Nishida E. Signalling through RHEB-1 mediates intermittent fasting-induced longevity in C. elegans. Nature. 2009:457(7230):726-30.

100. Lee SS, Kennedy S, Tolonen AC, Ruvkun G. DAF-16 target genes that control C. elegans life-span and metabolism. Science. 2003;300(5619):644-7.

101. Melendez A, Talloczy Z, Seaman M, Eskelinen EL, Hall DH, Levine B. Autophagy genes are essential for dauer development and life-span extension in C. elegans. Science. 2003;301(5638):1387-91.

102. Murphy CT, McCarroll SA, Bargmann Cl, Fraser A, Kamath RS, Ahringer J, $\mathrm{Li} \mathrm{H}$, Kenyon C. Genes that act downstream of DAF-16 to influence the lifespan of Caenorhabditis elegans. Nature. 2003;424(6946):277-83.

103. Uno M, Nishida E. Lifespan-regulating genes in C. elegans. NPJ Aging Mech Dis. 2016;2:16010.

104. Giannakou ME, Partridge L. Role of insulin-like signalling in Drosophila lifespan. Trends Biochem Sci. 2007;32(4):180-8.

105. Yamamoto R, Tatar $\mathrm{M}$. Insulin receptor substrate chico acts with the transcription factor FOXO to extend Drosophila lifespan. Aging Cell. 2011;10(4):729-32.

106. Hwangbo DS, Gershman B, Tu MP, Palmer M, Tatar M. Drosophila dFOXO controls lifespan and regulates insulin signalling in brain and fat body. Nature. 2004;429(6991):562-6.

107. Giannakou ME, Goss M, Junger MA, Hafen E, Leevers SJ, Partridge L. Long-lived Drosophila with overexpressed dFOXO in adult fat body. Science. 2004;305(5682):361.

108. Woodling NS, Rajasingam A, Minkley LJ, Rizzo A, Partridge L. Independent glial subtypes delay development and extend healthy lifespan upon reduced insulin-PI3K signalling. BMC Biol. 2020;18(1):124.

109. Giannakou ME, Goss M, Partridge L. Role of dFOXO in lifespan extension by dietary restriction in Drosophila melanogaster: not required, but its activity modulates the response. Aging Cell. 2008:7(2):187-98.

110. Dobson AJ, Ezcurra M, Flanagan CE, Summerfield AC, Piper MDW, Gems D, Alic N. Nutritional programming of lifespan by FOXO inhibition on sugar-rich diets. Cell Rep. 2017;18(2):299-306.

111. Kim SS, Lee CK. Growth signaling and longevity in mouse models. BMB Rep. 2019;52(1):70-85.

112. Flurkey K, Papaconstantinou J, Miller RA, Harrison DE. Lifespan extension and delayed immune and collagen aging in mutant mice with defects in growth hormone production. Proc Natl Acad Sci USA. 2001:98(12):6736-41.

113. Lorenzini A, Salmon AB, Lerner C, Torres C, Ikeno Y, Motch S, McCarter R, Sell C. Mice producing reduced levels of insulin-like growth factor type 1 display an increase in maximum, but not mean, life span. J Gerontol A Biol Sci Med Sci. 2014;69(4):410-9.

114. Holzenberger M, Dupont J, Ducos B, Leneuve P, Geloen A, Even PC, Cervera P, Le Bouc Y. IGF-1 receptor regulates lifespan and resistance to oxidative stress in mice. Nature. 2003:421(6919):182-7.

115. Nelson JF, Strong R, Bokov A, Diaz V, Ward W. Probing the relationship between insulin sensitivity and longevity using genetically modified mice. J Gerontol A Biol Sci Med Sci. 2012;67(12):1332-8.

116. Taguchi A, Wartschow LM, White MF. Brain IRS2 signaling coordinates life span and nutrient homeostasis. Science. 2007;317(5836):369-72.

117. Shimokawa I, Komatsu T, Hayashi N, Kim SE, Kawata T, Park S, Hayashi H, Yamaza $\mathrm{H}$, Chiba T, Mori R. The life-extending effect of dietary restriction requires Foxo3 in mice. Aging Cell. 2015;14(4):707-9.

118. Willcox BJ, Donlon TA, He Q, Chen R, Grove JS, Yano K, Masaki KH, Willcox DC, Rodriguez B, Curb JD. FOXO3A genotype is strongly associated with human longevity. Proc Natl Acad Sci USA. 2008;105(37):13987-92.

119. Anselmi CV, Malovini A, Roncarati R, Novelli V, Villa F, Condorelli G, Bellazzi R, Puca AA. Association of the FOXO3A locus with extreme longevity in a southern Italian centenarian study. Rejuvenation Res. 2009;12(2):95-104.

120. Flachsbart F, Caliebe A, Kleindorp R, Blanche $H$, von Eller-Eberstein $H$, Nikolaus S, Schreiber S, Nebel A. Association of FOXO3A variation with human longevity confirmed in German centenarians. Proc Natl Acad Sci USA. 2009:106(8):2700-5.

121. Li Y, Wang WJ, Cao H, Lu J, Wu C, Hu FY, Guo J, Zhao L, Yang F, Zhang YX, et al. Genetic association of FOXO1A and FOXO3A with longevity trait in Han Chinese populations. Hum Mol Genet. 2009;18(24):4897-904.

122. Soerensen M, Dato S, Christensen K, McGue M, Stevnsner T, Bohr VA, Christiansen L. Replication of an association of variation in the FOXO3A gene with human longevity using both case-control and longitudinal data. Aging Cell. 2010;9(6):1010-7.

123. Pawlikowska L, Hu D, Huntsman S, Sung A, Chu C, Chen J, Joyner AH, Schork NJ, Hsueh WC, Reiner AP, et al. Association of common genetic variation in the insulin/IGF1 signaling pathway with human longevity. Aging Cell. 2009;8(4):460-72.

124. Morris BJ, Chen R, Donlon TA, Evans DS, Tranah GJ, Parimi N, Ehret GB, Newton-Cheh C, Seto T, Willcox DC, et al. Association analysis of FOXO3 longevity variants with blood pressure and essential hypertension. Am J Hypertens. 2016;29(11):1292-300.

125. Flachsbart F, Dose J, Gentschew L, Geismann C, Caliebe A, Knecht C, Nygaard M, Badarinarayan N, ElSharawy A, May S, et al. Identification and characterization of two functional variants in the human longevity gene FOXO3. Nat Commun. 2017:8(1):2063.

126. Forte G, Grossi V, Celestini V, Lucisano G, Scardapane M, Varvara D, Patruno M, Bagnulo R, Loconte D, Giunti L, et al. Characterization of the rs2802292 SNP identifies FOXO3A as a modifier locus predicting cancer risk in patients with PJS and PHTS hamartomatous polyposis syndromes. BMC Cancer. 2014;14:661.

127. Banasik K, Ribel-Madsen R, Gjesing AP, Wegner L, Andersson A, Poulsen P, Borglykke A, Witte DR, Pedersen O, Hansen T, et al. The FOXO3A rs2802292 G-allele associates with improved peripheral and hepatic insulin sensitivity and increased skeletal muscle-FOXO3A mRNA expression in twins. J Clin Endocrinol Metab. 2011:96(1):E119-124.

128. Sanese P, Forte G, Disciglio V, Grossi V, Simone C. FOXO3 on the road to longevity: lessons from SNPs and chromatin hubs. Comput Struct Biotechnol J. 2019:17:737-45.

129. Furuyama T, Nakazawa T, Nakano I, Mori N. Identification of the differential distribution patterns of mRNAs and consensus binding sequences for mouse DAF-16 homologues. Biochem J. 2000;349(Pt 2):629-34.

130. Biggs WH 3rd, Cavenee WK, Arden KC. Identification and characterization of members of the FKHR (FOX O) subclass of winged-helix transcription factors in the mouse. Mamm Genome. 2001;12(6):416-25.

131. Hoekman MF, Jacobs FM, Smidt MP, Burbach JP. Spatial and temporal expression of FoxO transcription factors in the developing and adult murine brain. Gene Expr Patterns. 2006;6(2):134-40.

132. Gilels F, Paquette ST, Zhang J, Rahman I, White PM. Mutation of Foxo3 causes adult onset auditory neuropathy and alters cochlear synapse architecture in mice. J Neurosci. 2013;33(47):18409-24.

133. Salih DA, Rashid AJ, Colas D, de la Torre-Ubieta L, Zhu RP, Morgan AA, Santo EE, Ucar D, Devarajan K, Cole CJ, et al. FoxO6 regulates memory consolidation and synaptic function. Genes Dev. 2012;26(24):2780-801.

134. Polter A, Yang S, Zmijewska AA, van Groen T, Paik JH, Depinho RA, Peng SL, Jope RS, Li X. Forkhead box, class O transcription factors in brain: regulation and behavioral manifestation. Biol Psychiatry. 2009:65(2):150-9.

135. Ren H, Plum-Morschel L, Gutierrez-Juarez R, Lu TY, Kim-Muller JY, Heinrich G, Wardlaw SL, Silver R, Accili D. Blunted refeeding response and increased locomotor activity in mice lacking FoxO1 in synapsin-Creexpressing neurons. Diabetes. 2013;62(10):3373-83.

136. Kajimura D, Paone R, Mann JJ, Karsenty G. Foxo1 regulates Dbh expression and the activity of the sympathetic nervous system in vivo. Mol Metab. 2014:3(7):770-7.

137. Gilley J, Coffer PJ, Ham J. FOXO transcription factors directly activate bim gene expression and promote apoptosis in sympathetic neurons. J Cell Biol. 2003;162(4):613-22.

138. Barthelemy C, Henderson CE, Pettmann B. Foxo3a induces motoneuron death through the Fas pathway in cooperation with JNK. BMC Neurosci. 2004:5:48.

139. Papadia S, Soriano FX, Leveille F, Martel MA, Dakin KA, Hansen HH Kaindl A, Sifringer M, Fowler J, Stefovska V, et al. Synaptic NMDA receptor activity boosts intrinsic antioxidant defenses. Nat Neurosci. 2008;11(4):476-87.

140. Yuan Z, Lehtinen MK, Merlo P, Villen J, Gygi S, Bonni A. Regulation of neuronal cell death by MST1-FOXO1 signaling. J Biol Chem. 2009:284(17):11285-92.

141. Xie Q, Hao Y, Tao L, Peng S, Rao C, Chen H, You H, Dong MQ, Yuan Z. Lysine methylation of $\mathrm{FOXO} 3$ regulates oxidative stress-induced neuronal cell death. EMBO Rep. 2012;13(4):371-7.

142. Sun L, Zhao M, Liu M, Su P, Zhang J, Li Y, Yang X, Wu Z. Suppression of FoxO3a attenuates neurobehavioral deficits after traumatic brain 
injury through inhibiting neuronal autophagy. Behav Brain Res. 2018;337:271-9.

143. Sun L, Zhao M, Wang Y, Liu A, Lv M, Li Y, Yang X, Wu Z. Neuroprotective effects of miR-27a against traumatic brain injury via suppressing FoxO3a-mediated neuronal autophagy. Biochem Biophys Res Commun. 2017:482(4):1141-7.

144. Caballero-Caballero A, Engel T, Martinez-Villarreal J, Sanz-Rodriguez A, Chang P, Dunleavy M, Mooney CM, Jimenez-Mateos EM, Schindler CK, Henshall DC. Mitochondrial localization of the forkhead box class $\mathrm{O}$ transcription factor FOXO3a in brain. J Neurochem. 2013;124(6):749-56.

145. Zhao C, Deng W, Gage FH. Mechanisms and functional implications of adult neurogenesis. Cell. 2008;132(4):645-60.

146. Renault VM, Rafalski VA, Morgan AA, Salih DA, Brett JO, Webb AE, Villeda SA, Thekkat PU, Guillerey C, Denko NC, et al. FoxO3 regulates neural stem cell homeostasis. Cell Stem Cell. 2009;5(5):527-39.

147. Paik JH, Ding Z, Narurkar R, Ramkissoon S, Muller F, Kamoun WS, Chae $\mathrm{SS}$, Zheng $\mathrm{H}$, Ying $\mathrm{H}$, Mahoney J, et al. FoxOs cooperatively regulate diverse pathways governing neural stem cell homeostasis. Cell Stem Cell. 2009;5(5):540-53.

148. Yeo H, Lyssiotis CA, Zhang Y, Ying H, Asara JM, Cantley LC, Paik JH. FoxO3 coordinates metabolic pathways to maintain redox balance in neural stem cells. EMBO J. 2013;32(19):2589-602.

149. Schaffner I, Minakaki G, Khan MA, Balta EA, Schlotzer-Schrehardt U, Schwarz TJ, Beckervordersandforth R, Winner B, Webb AE, DePinho $\mathrm{RA}$, et al. FoxO function is essential for maintenance of autophagic flux and neuronal morphogenesis in adult neurogenesis. Neuron. 2018:99(6):1188-1203 e1186.

150. Kapoor S, Kim SM, Farook JM, Mir S, Saha R, Sen N. Foxo3a transcriptionally upregulates AQP4 and induces cerebral edema following traumatic brain injury. J Neurosci. 2013;33(44):17398-403.

151. Cui M, Huang Y, Tian C, Zhao Y, Zheng J. FOXO3a inhibits TNF-alphaand IL-1 beta-induced astrocyte proliferation: implication for reactive astrogliosis. Glia. 2011;59(4):641-54.

152. Rangarajan P, Karthikeyan A, Lu J, Ling EA, Dheen ST. Sirtuin 3 regulates Foxo3a-mediated antioxidant pathway in microglia. Neuroscience. 2015;311:398-414.

153. Jablonska B, Scafidi J, Aguirre A, Vaccarino F, Nguyen V, Borok E, Horvath $\mathrm{TL}$, Rowitch DH, Gallo V. Oligodendrocyte regeneration after neonatal hypoxia requires FoxO1-mediated p27Kip1 expression. J Neurosci. 2012;32(42):14775-93

154. Peymani M, Ghaedi K, Hashemi MS, Ghoochani A, Kiani-Esfahani A, Nasr-Esfahani MH, Baharvand $\mathrm{H}$. Ameliorating the effect of pioglitazone on LPS-induced inflammation of human oligodendrocyte progenitor cells. Cell Mol Neurobiol. 2018;38(2):517-27.

155. Du S, Jin F, Maneix L, Gedam M, Xu Y, Catic A, Wang MC, Zheng H. FoxO3 deficiency in cortical astrocytes leads to impaired lipid metabolism and aggravated amyloid pathology. Aging Cell. 2021;20(8): e13432.

156. Kitamura YI, Kitamura T, Kruse JP, Raum JC, Stein R, Gu W, Accili D. FoxO1 protects against pancreatic beta cell failure through NeuroD and MafA induction. Cell Metab. 2005;2(3):153-63.

157. Buteau J, Shlien A, Foisy S, Accili D. Metabolic diapause in pancreatic beta-cells expressing a gain-of-function mutant of the forkhead protein Foxo1. J Biol Chem. 2007:282(1):287-93.

158. Pajvani UB, Accili D. The new biology of diabetes. Diabetologia. 2015:58(11):2459-68.

159. Nakae J, Kitamura T, Silver DL, Accili D. The forkhead transcription factor Foxol (Fkhr) confers insulin sensitivity onto glucose-6-phosphatase expression. J Clin Invest. 2001;108(9):1359-67.

160. O'Neill BT, Bhardwaj G, Penniman CM, Krumpoch MT, Suarez Beltran PA, Klaus K, Poro K, Li M, Pan H, Dreyfuss JM, et al. FoxO transcription factors are critical regulators of diabetes-related muscle atrophy. Diabetes. 2019;68(3):556-70.

161. Alzheimer's Association. 2020 Alzheimer's disease facts and figures. Alzheimers Dement; 2020. www.alz.org.

162. Masters CL, Simms G, Weinman NA, Multhaup G, McDonald BL, Beyreuther K. Amyloid plaque core protein in Alzheimer disease and Down syndrome. Proc Natl Acad Sci USA. 1985;82(12):4245-9.

163. Wischik CM, Novak M, Thogersen HC, Edwards PC, Runswick MJ, Jakes $\mathrm{R}$, Walker JE, Milstein C, Roth M, Klug A. Isolation of a fragment of tau derived from the core of the paired helical filament of Alzheimer disease. Proc Natl Acad Sci USA. 1988:85(12):4506-10.
164. Hardy JA, Higgins GA. Alzheimer's disease: the amyloid cascade hypothesis. Science. 1992;256(5054):184-5.

165. Frost B, Jacks RL, Diamond MI. Propagation of tau misfolding from the outside to the inside of a cell. J Biol Chem. 2009;284(19):12845-52.

166. Kametani F, Hasegawa M. Reconsideration of amyloid hypothesis and tau hypothesis in Alzheimer's disease. Front Neurosci. 2018;12:25.

167. Manolopoulos KN, Klotz LO, Korsten P, Bornstein SR, Barthel A. Linking Alzheimer's disease to insulin resistance: the FoxO response to oxidative stress. Mol Psychiatry. 2010;15(11):1046-52.

168. Thathiah A, De Strooper B. The role of $G$ protein-coupled receptors in the pathology of Alzheimer's disease. Nat Rev Neurosci. 2011;12(2):73-87.

169. Vetrivel KS, Thinakaran G. Amyloidogenic processing of beta-amyloid precursor protein in intracellular compartments. Neurology. 2006;66(2 Suppl 1):S69-73.

170. Guo T, Noble W, Hanger DP. Roles of tau protein in health and disease. Acta Neuropathol. 2017;133(5):665-704.

171. Verwilst P, Kim HS, Kim S, Kang C, Kim JS. Shedding light on tau protein aggregation: the progress in developing highly selective fluorophores. Chem Soc Rev. 2018:47(7):2249-65.

172. Wang $X$, Wang Z, Chen Y, Huang X, Hu Y, Zhang R, Ho MS, Xue L. FoxO mediates APP-induced AICD-dependent cell death. Cell Death Dis. 2014;5: e1233.

173. Sanphui $\mathrm{P}$, Biswas SC. FoxO3a is activated and executes neuron death via Bim in response to beta-amyloid. Cell Death Dis. 2013;4: e625.

174. Akhter R, Sanphui P, Biswas SC. The essential role of p53-up-regulated modulator of apoptosis (Puma) and its regulation by FoxO3a transcription factor in beta-amyloid-induced neuron death. J Biol Chem. 2014:289(15):10812-22.

175. Wong HK, Veremeyko T, Patel N, Lemere CA, Walsh DM, Esau C, Vanderburg C, Krichevsky AM. De-repression of FOXO3a death axis by microRNA-132 and -212 causes neuronal apoptosis in Alzheimer's disease. Hum Mol Genet. 2013;22(15):3077-92.

176. Nuzzo D, Picone P, Baldassano S, Caruana L, Messina E, Marino Gammazza A, Cappello F, Mule F, Di Carlo M. Insulin resistance as common molecular denominator linking obesity to Alzheimer's disease. Curr Alzheimer Res. 2015;12(8):723-35.

177. Fernandez AM, Hervas R, Dominguez-Fraile M, Garrido VN, GomezGutierrez P, Vega M, Vitorica J, Perez JJ, Torres Aleman I. Blockade of the interaction of calcineurin with FOXO in astrocytes protects against amyloid-beta-induced neuronal death. J Alzheimers Dis. 2016;52(4):1471-8.

178. Saha P, Biswas SC. Amyloid-beta induced astrocytosis and astrocyte death: implication of FoxO3a-Bim-caspase3 death signaling. Mol Cell Neurosci. 2015;68:203-11.

179. Shi C, Zhu J, Leng S, Long D, Luo X. Mitochondrial FOXO3a is involved in amyloid beta peptide-induced mitochondrial dysfunction. J Bioenerg Biomembr. 2016:48(3):189-96.

180. Qin W, Zhao W, Ho L, Wang J, Walsh K, Gandy S, Pasinetti GM. Regulation of forkhead transcription factor FoxO3a contributes to calorie restriction-induced prevention of Alzheimer's disease-type amyloid neuropathology and spatial memory deterioration. Ann NY Acad Sci. 2008;1147:335-47.

181. Guo $P$, Wang D, Wang $X$, Feng $H$, Tang Y, Sun R, Zheng Y, Dong L, Zhao J, Zhang $X$, et al. Effect and mechanism of fuzhisan and donepezil on the sirtuin 1 pathway and amyloid precursor protein metabolism in PC12 cells. Mol Med Rep. 2016;13(4):3539-46.

182. Lin CL, Huang WN, Li HH, Huang CN, Hsieh S, Lai C, Lu FJ. Hydrogen-rich water attenuates amyloid beta-induced cytotoxicity through upregulation of Sirt1-FoxO3a by stimulation of AMP-activated protein kinase in SK-N-MC cells. Chem Biol Interact. 2015:240:12-21.

183. Omata Y, Lim YM, Akao Y, Tsuda L. Age-induced reduction of autophagy-related gene expression is associated with onset of Alzheimer's disease. Am J Neurodegener Dis. 2014;3(3):134-42.

184. Sajan M, Hansen B, Ivey R 3rd, Sajan J, Ari C, Song S, Braun U, Leitges M, Farese-Higgs $M$, Farese RV. Brain insulin signaling is increased in insulinresistant states and decreases in FOXOs and PGC-1alpha and Increases in Abeta 1-40/42 and phospho-tau may abet alzheimer development. Diabetes. 2016;65(7):1892-903.

185. Shi C, Viccaro K, Lee HG, Shah K. Cdk5-Foxo3 axis: initially neuroprotective, eventually neurodegenerative in Alzheimer's disease models. J Cell Sci. 2016:129(9):1815-30. 
186. Pino E, Amamoto R, Zheng L, Cacquevel M, Sarria JC, Knott GW, Schneider BL. FOXO3 determines the accumulation of alpha-synuclein and controls the fate of dopaminergic neurons in the substantia nigra. Hum Mol Genet. 2014;23(6):1435-52.

187. Webb AE, Brunet A. FOXO transcription factors: key regulators of cellular quality control. Trends Biochem Sci. 2014;39(4):159-69.

188. Liu YY, Zhang YN, Yang QS. Downregulated expression of microRNA-329 inhibits apoptosis of nigral dopaminergic neurons by regulating CDKN2D expression via the FoxO3a signaling pathway in rats with Parkinson's disease. J Cell Physiol. 2018;233(11):8617-29.

189. Koh H, Kim H, Kim MJ, Park J, Lee HJ, Chung J. Silent information regulator 2 (Sir2) and Forkhead box O (FOXO) complement mitochondrial dysfunction and dopaminergic neuron loss in Drosophila PTEN-induced kinase 1 (PINK1) null mutant. J Biol Chem. 2012;287(16):12750-8.

190. Kanao T, Sawada T, Davies SA, Ichinose H, Hasegawa K, Takahashi R, Hattori N, Imai Y. The nitric oxide-cyclic GMP pathway regulates FoxO and alters dopaminergic neuron survival in Drosophila. PLoS ONE. 2012;7(2): e30958.

191. Davila D, Torres-Aleman I. Neuronal death by oxidative stress involves activation of $\mathrm{FOXO} 3$ through a two-arm pathway that activates stress kinases and attenuates insulin-like growth factor I signaling. Mol Biol Cell. 2008;19(5):2014-25.

192. Bahia PK, Pugh V, Hoyland K, Hensley V, Rattray M, Williams RJ. Neuroprotective effects of phenolic antioxidant $\mathrm{tBHQ}$ associate with inhibition of FoxO3a nuclear translocation and activity. J Neurochem. 2012;123(1):182-91.

193. Davila D, Connolly NM, Bonner H, Weisova P, Dussmann H, Concannon CG, Huber HJ, Prehn JH. Two-step activation of FOXO3 by AMPK generates a coherent feed-forward loop determining excitotoxic cell fate. Cell Death Differ. 2012:19(10):1677-88.

194. Mojsilovic-Petrovic J, Nedelsky N, Boccitto M, Mano I, Georgiades SN, Zhou W, Liu Y, Neve RL, Taylor JP, Driscoll M, et al. FOXO3a is broadly neuroprotective in vitro and in vivo against insults implicated in motor neuron diseases. J Neurosci. 2009;29(25):8236-47.

195. Jiang M, Wang J, Fu J, Du L, Jeong H, West T, Xiang L, Peng Q, Hou Z, Cai $\mathrm{H}$, et al. Neuroprotective role of Sirt1 in mammalian models of Huntington's disease through activation of multiple Sirt1 targets. Nat Med. 2011;18(1):153-8.

196. Vidal RL, Figueroa A, Court FA, Thielen P, Molina C, Wirth C, Caballero B, Kiffin R, Segura-Aguilar J, Cuervo AM, et al. Targeting the UPR transcription factor XBP1 protects against Huntington's disease through the regulation of FoxO1 and autophagy. Hum Mol Genet. 2012;21(10):2245-62.

197. Apfeld J, Kenyon C. Cell nonautonomy of C. elegans daf-2 function in the regulation of diapause and life span. Cell. 1998;95(2):199-210.

198. Wolkow CA, Kimura KD, Lee MS, Ruvkun G. Regulation of C. elegans life-span by insulinlike signaling in the nervous system. Science. 2000;290(5489):147-50.
199. Libina N, Berman JR, Kenyon C. Tissue-specific activities of C. elegans DAF-16 in the regulation of lifespan. Cell. 2003;115(4):489-502.

200. Jayaraman A, Pike CJ. Alzheimer's disease and type 2 diabetes: multiple mechanisms contribute to interactions. Curr Diab Rep. 2014;14(4):476.

201. Butterfield DA, Halliwell B. Oxidative stress, dysfunctional glucose metabolism and Alzheimer disease. Nat Rev Neurosci. 2019;20(3):148-60.

202. Talbot K, Wang HY, Kazi H, Han LY, Bakshi KP, Stucky A, Fuino RL, Kawaguchi KR, Samoyedny AJ, Wilson RS, et al. Demonstrated brain insulin resistance in Alzheimer's disease patients is associated with IGF-1 resistance, IRS-1 dysregulation, and cognitive decline. J Clin Invest. 2012;122(4):1316-38.

203. Moloney AM, Griffin RJ, Timmons S, O'Connor R, Ravid R, O'Neill C. Defects in IGF-1 receptor, insulin receptor and IRS-1/2 in Alzheimer's disease indicate possible resistance to IGF-1 and insulin signalling. Neurobiol Aging. 2010;31(2):224-43.

204. Janson J, Laedtke T, Parisi JE, O'Brien P, Petersen RC, Butler PC. Increased risk of type 2 diabetes in Alzheimer disease. Diabetes. 2004;53(2):474-81.

205. Li ZG, Zhang W, Sima AA. Alzheimer-like changes in rat models of spontaneous diabetes. Diabetes. 2007;56(7):1817-24.

206. Jung HJ, Kim YJ, Eggert S, Chung KC, Choi KS, Park SA. Agedependent increases in tau phosphorylation in the brains of type 2 diabetic rats correlate with a reduced expression of p62. Exp Neurol. 2013;248:441-50.

207. Kim B, Backus C, Oh S, Hayes JM, Feldman EL. Increased tau phosphorylation and cleavage in mouse models of type 1 and type 2 diabetes. Endocrinology. 2009;150(12):5294-301.

208. Ho L, Qin W, Pompl PN, Xiang Z, Wang J, Zhao Z, Peng Y, Cambareri G, Rocher A, Mobbs CV, et al. Diet-induced insulin resistance promotes amyloidosis in a transgenic mouse model of Alzheimer's disease. FASEB J. 2004;18(7):902-4.

209. Cao D, Lu H, Lewis TL, Li L. Intake of sucrose-sweetened water induces insulin resistance and exacerbates memory deficits and amyloidosis in a transgenic mouse model of Alzheimer disease. J Biol Chem. 2007;282(50):36275-82.

210. Birnbaum A, Wu X, Tatar M, Liu N, Bai H. Age-dependent changes in transcription factor FOXO targeting in female Drosophila. Front Genet. 2019;10:312.

\section{Publisher's Note}

Springer Nature remains neutral with regard to jurisdictional claims in published maps and institutional affiliations.
Ready to submit your research? Choose BMC and benefit from:

- fast, convenient online submission

- thorough peer review by experienced researchers in your field

- rapid publication on acceptance

- support for research data, including large and complex data types

- gold Open Access which fosters wider collaboration and increased citations

- maximum visibility for your research: over $100 \mathrm{M}$ website views per year

At BMC, research is always in progress.

Learn more biomedcentral.com/submissions 